\title{
Biological Activities of Methanolic Extract of Aegle marmelos against HN Protein of Newcastle Disease Virus
}

\author{
Rahat Andleeb ${ }^{1}$, Muhammad Umar Ijaz ${ }^{2}$, Azhar Rafique ${ }^{1}$, Asma Ashraf ${ }^{1, *} \mathbb{(}$, Naheed Bano ${ }^{3}$, Nimrah Zafar ${ }^{1}$, \\ Faisal Tasleem ${ }^{4}$, Romina Alina Marc (Vlaic) ${ }^{5, *}$, Oana Lelia Pop ${ }^{6}\left(\mathbb{B}\right.$ and Hanadi Talal Ahmedah ${ }^{7}$ \\ check for \\ updates \\ 1 Department of Zoology, Government College University Faisalabad, Allama Iqbal Road, \\ Faisalabad 38000, Pakistan; rahatandleeb22@gcuf.edu.pk (R.A.); azharrafique96@gmail.com (A.R.); \\ nimrahzafar14@gmail.com (N.Z.) \\ 2 Department of Zoology, Wildlife and Fisheries, University of Agriculture, Faisalabad 38040, Pakistan; \\ umar.ijaz@uaf.edu.pk \\ 3 Faculty of Veterinary and Animal Sciences, MNS-University of Agriculture, Multan 60000, Pakistan; \\ bnaheed61@gmail.com \\ 4 Department of Biochemistry, University of Agriculture, Faisalabad 38040, Pakistan; \\ faisaltasleem694@gmail.com \\ 5 Food Engineering Department, Faculty of Food Science and Technology, University of Agricultural Sciences \\ and Veterinary Medicine, 400372 Cluj-Napoca, Romania \\ 6 Department of Food Science, University of Agricultural Science and Veterinary Medicine, \\ 400372 Cluj-Napoca, Romania; oana.pop@usamvcluj.ro \\ 7 Department of Medical Laboratory Technology, Faculty of Applied Medical Sciences, \\ King Abdulaziz University, Rabigh 25732, Saudi Arabia; hehmedouh@kau.edu.sa \\ * Correspondence: asmabinm@gmail.com (A.A.); romina.vlaic@usamvcluj.ro (R.A.M.)
}

Citation: Andleeb, R.; Ijaz, M.U.; Rafique, A.; Ashraf, A.; Bano, N.; Zafar, N.; Tasleem, F.; Marc, R.A.; Pop, O.L.; Ahmedah, H.T. Biological Activities of Methanolic Extract of Aegle marmelos against HN Protein of Newcastle Disease Virus. Agronomy 2021, 11, 1784. https://doi.org/ 10.3390/agronomy11091784

Academic Editors: Jaime Carrasco and Francisco J. Gea

Received: 29 July 2021

Accepted: 30 August 2021

Published: 6 September 2021

Publisher's Note: MDPI stays neutral with regard to jurisdictional claims in published maps and institutional affiliations.

Copyright: (C) 2021 by the authors. Licensee MDPI, Basel, Switzerland. This article is an open access article distributed under the terms and conditions of the Creative Commons Attribution (CC BY) license (https:/ / creativecommons.org/licenses/by/ $4.0 /)$.
Abstract: The current study explores the methanolic extracts of the leaves and fruit of Aegle marmelos (Bael) for their total phenolic content (TPC), total flavonoids content (TFC), antioxidants, and antibiofilms, as well as its in ovo antiviral potential against Newcastle disease virus (NDV). The druglikeliness thereof and the potential identification of an interaction - their molecular docking of ligands with target proteins by GOLD—was determined in silico using the Swiss ADME software. The total flavonoids content (TFC) was $135.17 \pm 2.02$ and $111.2 \pm 3.67 \mathrm{mg} \mathrm{QE} / \mathrm{g}$, while the total phenolics content (TPC) was $185.02 \pm 2.15$ and $171.13 \pm 6.73 \mathrm{mg} \mathrm{GAE} / \mathrm{g}$, in the fruit and leaves extracts, respectively. In a DPPH assay, the $\mathrm{IC}_{50}$ value for the methanolic extracts of leaves and fruit was $63.52 \pm 1.48$ and $52.06 \pm 1.62 . \mu \mathrm{g} / \mathrm{mL}$ d.w. The fruit extract of $A$. marmelos showed significantly higher reducing power (i.e., $59.32 \pm 0.05 \mu \mathrm{mol} / \mathrm{g}$ d.w) than the leaves extract $(p<0.05)$. The biofilm-inhibition activity of the fruit extract of $A$. marmelos was $65.78 \pm 0.65 \mu \mathrm{g} / \mathrm{mL}$. Both parts of the plant showed potent antiviral potential at higher concentrations. A study in silico, using the molecular docking of three compounds, showed good interaction with the HN protein, with considerable binding affinities and fulfilled docking parameters. This work shows that Aegle marmelos and its phytoconstituents can be used as a potential remedy for NDV.

Keywords: Aegle marmelos; in vitro; in ovo; in silico; molecular docking; NDV

\section{Introduction}

Newcastle Disease (ND) is a severe avian disease caused by a poultry-effecting RNA virus, Newcastle disease virus (NDV) [1]. NDV is encoded by six major glycoproteins, from which two transmembrane proteins, hemagglutinin-neuraminidase (HN) and fusion F, are eligible for the binding and fusion of the virus with the host cell by conformational alteration [2]. Due to its infection and mortality statistics, this disease places significant burden on the poultry industry [3], destroying 70 to 80 percent of unvaccinated, rural poultry each year [4]. Of the currently available vaccines, only a few are proven to be efficient [5]. Vaccination can preclude clinical symptoms, but replication and virus shedding 
cannot be stopped, hence the urgency in finding antivirals and new corresponding practices that are healthy, reliable, have fewer side effects and are not overwhelmed by resistance $[6,7]$. Therefore, medicinal plants are being screened to combat NDV.

Plants defend themselves against microbes and insects by producing various secondary metabolites, such as alkaloids, phenolic compounds (flavonoids, isoflavonoids, and anthocyanins), and terpenoids [8], which have gained importance due to their antioxidant, antiviral, antibacterial, and anticancer effects [9]. Coumarin and its derivatives have been observed to show similar antiviral activity against a wide range of viruses, such as influenza viruses, HIV, enterovirus 71 (EV71), coxsackievirus A16 (CVA16), dengue virus, and chikungunya virus. These metabolites have an ability to combat other viruses infecting both animals and humans [10]. Phytochemicals are responsible for the therapeutic effects of plants [11,12]. These bioactive compounds, present in medicinal plants, can quell radical substances by electron donation and, eventually, stop the radical chain reaction, thereby protecting the body against the various diseases produced by reactive oxygen species (ROS) [13]. The pursuit of new drugs, based upon ethnobotany and ethnopharmacology, has led to the discovery of new natural products that can avert human and animal viral ailments [14]. About $50 \%$ of medicines in use are derived from plants and their constituents [15]. Antivirals can have either a protective or curative effect on a host cell infected by a virus. Research has focused on antivirals isolated or extracted from medicinal plants for many years [16].

Aegle marmelos, commonly known as bael, is found in most of the countries of South Asia, including Pakistan [17-19]. Its leaves, fruit, stems, and roots are used in the treatment of viral illnesses [20-22]. To rationalize the traditional uses of $A$. marmelos against various ailments, the present research explores the total phenolic content, total flavonoids content, antioxidants, anti-biofilms, and the antiviral potential of the leaves and fruit extracts of $A$. marmelos. To predict the actions of individual bioactive compounds as potential medicines, a physicochemical description, and the solubility, lipophilicity, pharmacokinetic characteristics, drug design, and medicine-likeliness of these extracts were investigated using the Swiss ADME online software.

\section{Results}

\subsection{Determination of Total Phenolics Contents and Total Flavonoids Contents}

The total phenolic contents in both the fruit and leaves extracts of $A$. marmelos were determined using the Folin-Ciocalteu method, using gallic acid (GE) as the standard. The absorbance values obtained at different concentrations of GE were used for the construction of the calibration curve. The TPC values were higher in the fruit than in the leaves extracts. The TPC value of the fruit extract was $185.02 \pm 2.15 \mathrm{mg}$ GAE $/ \mathrm{g} \mathrm{d} . \mathrm{w}$ and that for leaves was $171.13 \pm 6.73 \mathrm{mg} \mathrm{GAE} / \mathrm{g}$. (Table 1). Flavonoids, phenols, and tannins are extremely valuable compounds for the free radical scavenging mechanism [23].

Table 1. Total phenolic contents and total flavonoids contents of the methanolic extract of A. marmelos.

\begin{tabular}{ccccc}
\hline & Fruit & Leaves & Fruit & Leaves \\
\hline $\begin{array}{c}\text { Concentrations } \\
(\mu \mathbf{g} / \mathbf{m L} \text { d.w) }\end{array}$ & $\begin{array}{c}\text { TPC } \\
\text { m g GAE/g }\end{array}$ & $\begin{array}{c}\text { TPC } \\
\text { mg GAE/g }\end{array}$ & $\begin{array}{c}\text { TFC } \\
\text { mg QE/g }\end{array}$ & $\begin{array}{c}\text { TFC } \\
\text { mg QE/g }\end{array}$ \\
25 & $181.48^{\mathrm{a}}$ & $162.93^{\mathrm{b}}$ & $138.16^{\mathrm{a}}$ & $116.36^{\mathrm{ab}}$ \\
50 & $185.18^{\mathrm{a}}$ & $168.51^{\mathrm{b}}$ & $134.54^{\mathrm{a}}$ & $109.08^{\mathrm{b}}$ \\
75 & $186.41^{\mathrm{a}}$ & $171.6^{\mathrm{ab}}$ & $132.54^{\mathrm{a}}$ & $106.66^{\mathrm{c}}$ \\
100 & $187.03^{\mathrm{a}}$ & $181.48^{\mathrm{a}}$ & $135.45^{\mathrm{a}}$ & $112.72^{\mathrm{bc}}$ \\
Mean values & $185.02 \pm 2.15$ & $171.13 \pm 6.73$ & $135.17 \pm 2.02$ & $111.2 \pm 3.67$ \\
\hline
\end{tabular}

The values are reported as mean \pm SEM values $(n=4)$. Identical superscripts letters within rows indicate no significant difference $(p>0.05)$.

The TFC values showed similar trends with that of the TPC values. The mean TFC values were $135.17 \pm 2.02 \mathrm{mg}$ and $111.2 \pm 3.67 \mathrm{mg}$ QE $/ \mathrm{g}$ for the fruit and leaves, respectively. 


\subsection{Antioxidant Activity}

\subsubsection{DPPH Assay}

The stable free radical approach of DPPHs has been rationalized as a preliminary indicator of antioxidant activity. The higher $\mathrm{IC}_{50}$ value indicates lower radical scavenging activity or lower antioxidant potential. The leaves extract of $A$. marmelos showed an $\mathrm{IC}_{50}$ value $63.52 \pm 1.48$, while the fruit extract showed $52.06 \pm 1.62 \mu \mathrm{g} / \mathrm{mL}$ d.w. (Figure 1A). Ascorbic acid was used as the standard and the different extracts showed variable antioxidant properties. It was determined that due to the existence of antioxidant properties in the samples, the plant extracts decreased the stable DPPH radical content and minimized color changes [24]. The $\mathrm{IC}_{50}$ value of ascorbic acid was $76.22 \mu \mathrm{g} / \mathrm{mL}$ d.w.
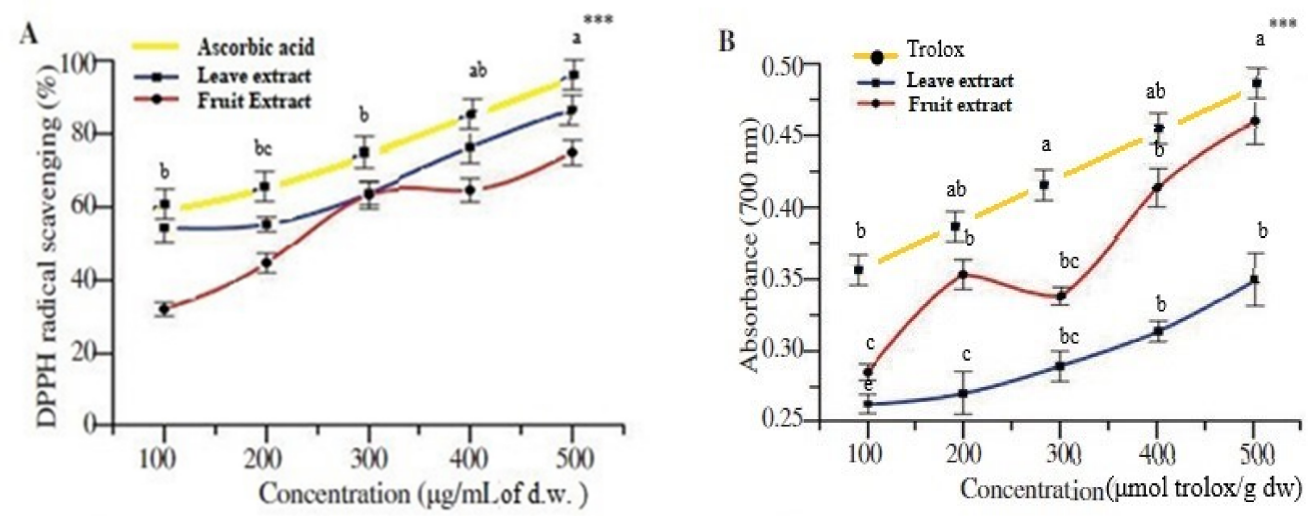

Figure 1. Antioxidant activity of A. marmelos leaves and fruit methanolic extracts. (A) DPPH free radical scavenging activity. (B) FRAP activity. Means in the same column not followed by a common letters are significantly different $(p<0.05) .{ }^{* * *}=$ highly significant.

\subsubsection{FRAP Activity}

A ferric-reducing antioxidant power assay using the potassium ferric cyanide reduction process was adopted for the evaluation of an antioxidant assay. By altering the color of the test solution, this method relies on the reduction of $\mathrm{Fe}^{3+}$ to $\mathrm{Fe}^{2+}$. The $\mathrm{IC}_{50}$ for trolox was $75.5 \mu \mathrm{mol} / \mathrm{g}$ d.w. Notably, the A. marmelos fruit extract showed a significantly higher reduction power compared to the leaf extract $(p<0.05)$ (Figure $1 \mathrm{~B})$. The $\mathrm{IC}_{50}$ for the fruit was $59.32 \pm 0.05 \mu \mathrm{mol} / \mathrm{g}$ d.w and the leaves have an $\mathrm{IC}_{50}$ value of $46.5 \pm 0.25 \mu \mathrm{mol} / \mathrm{g}$ d.w. This result was in accordance with the earlier reports depicting the increase in the reduction power with a concomitant increase in the plant extract concentration $[25,26]$.

\subsection{Anti-Biofilm Activity}

The current research highlights the anti-biofilm potential of the methanolic extracts of the fruit and leaves of $A$. marmelos against E. coli. The results (Table 2) indicate that the fruit extract has a maximum inhibitory activity of $65.78 \pm 0.65$ against $E$. coli with the maximum inhibition diameter zone, followed by the leaves extract $>$ the control, as shown in Figure 2A-C.

Table 2. Optical densities of biofilms inhibition (\%) by extracts of $A$. marmelos.

\begin{tabular}{cc}
\hline Aegle marmelos & Biofilm Inhibition (\%) against E. coli \\
\hline Leaves & $59.31 \pm 0.91^{\mathrm{b}}$ \\
Fruit & $65.78 \pm 0.65^{\mathrm{bc}}$ \\
Control & $0.05 \pm 0.004^{\mathrm{a}}$ \\
\hline
\end{tabular}

The values are reported as mean \pm SEM values. Identical superscripts letters within rows indicate no significant difference $(p>0.05)$ 


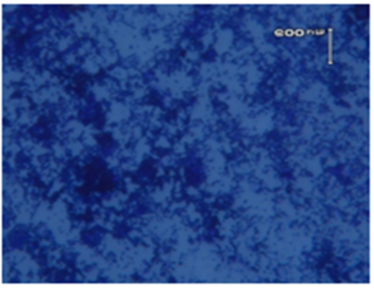

(A)

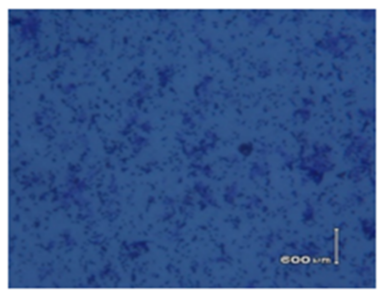

(B)

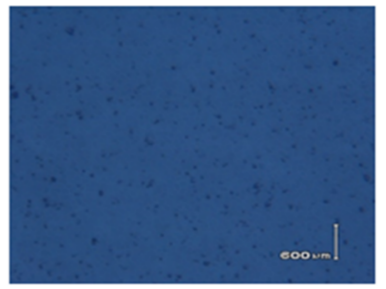

(C)

Figure 2. Phase contrast microscopic view of inhibition of $E$. coli biofilm by extracts of leaves and fruit of A. marmelos. (A) Negative control E. coli biofilm. (B) Biofilm treated with leaves extract (C) Biofilm treated with fruit extract.

\subsection{In Ovo Antiviral Activity}

Median Percent Embryo Infectious Dose

The NDV concentration in a suspension is expressed as an infectivity titer. The infectivity titer is established by performing a titration method created by Reed and Muench; the formula is as follows:

Dilution $=\frac{(\text { Mortality at dilution just above } 50 \%-50 \%)}{\text { Mortality at dilution just above } 50 \%-\% \text { Mortality at dilution just below } 50 \%}$

Applying the index calculated using this formula to the dilution produced an infection rate immediately above $50 \%$ yield $10^{-4.5}$.

Time for embryo death: We evaluated the antiviral efficacy of the A. marmelos extracts using an in ovo technique against NDV in the embryonated eggs of chickens. Various embryo mortalities of the extract/virus suspension of leaves and fruit inoculated groups were observed, and the associated HA test was executed. The results (Table 3 ) indicate that the virus-inoculated eggs (G2) were all dead between $48-72 \mathrm{~h}$ after inoculation and showed a positive hemagglutination titer for all the allantoic fluid. The HA titer value for this group was 2048, suggesting that the virus was live until the end. The eggs treated with both the fruit and leaves extract controls of G4 and G5, (i.e., $75 \mu \mathrm{g} / \mathrm{mL}$ of extract) had a $0 \%$ mortality until 72-h post inoculation. The HA showed no titer with both of these extract control groups' allantoic fluid eggs. The fruit extract at 90 and $120 \mu \mathrm{g} / \mathrm{mL}$ showed $0 \%$ mortality until $72 \mathrm{~h}$, which indicates that at a high concentration, the fruit extract showed antiviral activity with a complete inhibition of virus replication. However, the 30 and $60 \mu \mathrm{g} / \mathrm{mL}$ concentrations of the fruit extract did not stop virus replication completely and triggered embryo death in 20 and $40 \%$ of cases, respectively, as shown by their HA titer values (Table 3).

Table 3. Mortality (\%) and HA assay of fruit and leaves extracts.

\begin{tabular}{|c|c|c|c|c|c|c|}
\hline \multirow{2}{*}{ Treatment } & \multirow{2}{*}{$\begin{array}{c}\text { Concentration } \\
(\mu \mathrm{g} / \mathrm{mL})\end{array}$} & \multicolumn{3}{|c|}{ Time of Embryo Death (h) } & \multirow{2}{*}{ Mortality \% } & \multirow{2}{*}{ HA Titer } \\
\hline & & $24 \mathrm{~h}$ & $48 \mathrm{~h}$ & $72 \mathrm{~h}$ & & \\
\hline Uninoculated egg & \multirow{4}{*}{75} & 0 & 0 & 0 & $0 \%$ & 0 \\
\hline$N D V$ alone & & 0 & 1 & 4 & $100 \%$ & 2048 \\
\hline$N D V+\mathrm{DMSO}$ & & 0 & 5 & - & $100 \%$ & 1024 \\
\hline Fruit Extract only & & 0 & 0 & 0 & $0 \%$ & 0 \\
\hline Leaves Extract only & 75 & 0 & 0 & 0 & $0 \%$ & 0 \\
\hline \multirow{4}{*}{$\begin{array}{l}\text { Methanolic extract of } \\
\text { fruit }+N D V\end{array}$} & 30 & 0 & 0 & 1 & $20 \%$ & 16 \\
\hline & 60 & 0 & 1 & 1 & $40 \%$ & 32 \\
\hline & 90 & 0 & 0 & 0 & $0 \%$ & 0 \\
\hline & 120 & 0 & 0 & 0 & $0 \%$ & 0 \\
\hline
\end{tabular}


Table 3. Cont.

\begin{tabular}{|c|c|c|c|c|c|c|}
\hline \multirow{2}{*}{ Treatment } & \multirow{2}{*}{$\begin{array}{l}\text { Concentration } \\
(\mu \mathrm{g} / \mathrm{mL})\end{array}$} & \multicolumn{3}{|c|}{ Time of Embryo Death (h) } & \multirow{2}{*}{ Mortality \% } & \multirow{2}{*}{ HA Titer } \\
\hline & & $24 \mathrm{~h}$ & $48 \mathrm{~h}$ & $72 \mathrm{~h}$ & & \\
\hline \multirow{4}{*}{$\begin{array}{c}\text { Methanolic extract of } \\
\text { leaves }+N D V\end{array}$} & 30 & 0 & 0 & 1 & $20 \%$ & 16 \\
\hline & 60 & 0 & 1 & 0 & $20 \%$ & 8 \\
\hline & 90 & 0 & 0 & 0 & $0 \%$ & 0 \\
\hline & 120 & 0 & 1 & 1 & $40 \%$ & 32 \\
\hline
\end{tabular}

In contrast to this, the leaves extract at 30 and $60 \mu \mathrm{g} / \mathrm{mL}$ caused $20 \%$ mortality in the embryos, while the leaves extract at $90 \mu \mathrm{g} / \mathrm{mL}$ showed a good antiviral response, as, at this concentration, the death rate was $0 \%$, which indicated the efficacy of this dose. Four embryos were recorded as dead in the $120 \mu \mathrm{g} / \mathrm{mL}$ inoculated group, which indicates that this dose is lethal for embryos at a high concentration. The outcome of the in ovo analysis revealed that $A$. marmelos was a non-toxic and beneficial herbal plant against the ND virus at higher concentrations ( 90 and $120 \mu \mathrm{g} / \mathrm{mL}$ ) of fruit extract and $90 \mu \mathrm{g} / \mathrm{mL}$ of leaves extract with a complete inhibition of virus growth (Table 3 ).

\subsection{In Silico Swiss ADME Analysis}

\subsubsection{Physicochemical Properties}

The physicochemical properties of a drug significantly affect its metabolic destiny in the body. Table 4 shows that the molecular weight of all the compounds met the criterion (which should be $\leq 500 \mathrm{~g} / \mathrm{mol}$ ) with the exception of rutin (MW $610.52 \mathrm{~g} / \mathrm{mol}$ ). All of the studied compounds have less than 10 rotatable bonds. Further, the molar refractivity of all the compounds was within the acceptable range (40 and 130) except gallic acid, protocatechuic acid, and rutin. These three compounds satisfy the criteria for oral bioavailability.

Table 4. Physiochemical prediction of selected compounds of A. marmelos.

\begin{tabular}{|c|c|c|c|c|c|c|c|c|c|c|c|}
\hline \multicolumn{12}{|c|}{ Physiochemical Properties } \\
\hline Sr. No. & Compound & Formula & MW & $\begin{array}{l}\text { Fraction } \\
\text { Csp3 }\end{array}$ & RB & HBA & HBD & MR & TPSA & ESOL & $\begin{array}{l}\text { Lipophilicity } \\
\text { Conseco Log } p\end{array}$ \\
\hline 1 & Marmelide & $\mathrm{C}_{16} \mathrm{H}_{14} \mathrm{O}_{4}$ & $270.28 \mathrm{~g} / \mathrm{mol}$ & 0.19 & 3 & 4 & 0 & 77.50 & 52.58 & M. SOL & 3.31 \\
\hline 2 & Marmelon & $\mathrm{C}_{19} \mathrm{H}_{24} \mathrm{O}_{6}$ & $348.39 \mathrm{~g} / \mathrm{mol}$ & 0.42 & 8 & 6 & 2 & 95.21 & 89.13 & M. SOL & 2.23 \\
\hline 3 & Scoparone & $\mathrm{C}_{11} \mathrm{H}_{10} \mathrm{O}_{4}$ & $206.19 \mathrm{~g} / \mathrm{mol}$ & 0.18 & 2 & 4 & 0 & 55.47 & 48.67 & SOL & 1.84 \\
\hline 4 & Scopoletin & $\mathrm{C}_{10} \mathrm{H}_{8} \mathrm{O}_{4}$ & $192.17 \mathrm{~g} / \mathrm{mol}$ & 0.10 & 1 & 4 & 1 & 51.00 & 59.67 & SOL & 1.52 \\
\hline 5 & Alloimperatorin & $\mathrm{C}_{16} \mathrm{H}_{14} \mathrm{O}_{4}$ & $270.28 \mathrm{~g} / \mathrm{mol}$ & 0.19 & 2 & 4 & 1 & 78.00 & 63.58 & M. SOL & 3.27 \\
\hline 6 & $\begin{array}{c}6,7- \\
\text { epoxyauraptene }\end{array}$ & $\mathrm{C}_{19} \mathrm{H}_{22} \mathrm{O}_{4}$ & $314.38 \mathrm{~g} / \mathrm{mol}$ & 0.42 & 6 & 4 & 0 & 90.77 & 51.97 & M. SOL & 3.90 \\
\hline 7 & Caffeic acid & $\mathrm{C}_{9} \mathrm{H}_{8} \mathrm{O}_{4}$ & $180.16 \mathrm{~g} / \mathrm{mol}$ & 0.00 & 2 & 4 & 3 & 47.16 & 77.76 & V. SOL & 0.83 \\
\hline 8 & Quercetin & $\mathrm{C}_{15} \mathrm{H}_{10} \mathrm{O}_{7}$ & $302.24 \mathrm{~g} / \mathrm{mol}$ & 0.00 & 1 & 7 & 5 & 78.04 & 131.36 & SOL & 1.23 \\
\hline 9 & Catechin & $\mathrm{C}_{15} \mathrm{H}_{14} \mathrm{O}_{6}$ & $290.27 \mathrm{~g} / \mathrm{mol}$ & 0.20 & 1 & 6 & 5 & 74.33 & 110.38 & SOL & 0.931 \\
\hline 10 & Skimmianine & $\mathrm{C}_{12} \mathrm{H}_{13} \mathrm{NO}_{3}$ & $219.24 \mathrm{~g} / \mathrm{mol}$ & 0.25 & 3 & 4 & 0 & 61.22 & 40.58 & SOL & 1.96 \\
\hline 11 & $\begin{array}{c}\text { Chlorogenic } \\
\text { acid }\end{array}$ & $\mathrm{C}_{16} \mathrm{H}_{18} \mathrm{O}_{9}$ & $354.31 \mathrm{~g} / \mathrm{mol}$ & 0.38 & 5 & 9 & 6 & 83.50 & 164.75 & V. SOL & 0.39 \\
\hline 12 & Gallic acid & $\mathrm{C}_{7} \mathrm{H}_{6} \mathrm{O}_{5}$ & $170.12 \mathrm{~g} / \mathrm{mol}$ & 0.00 & 1 & 5 & 4 & 39.47 & 97.99 & V. SOL & 0.21 \\
\hline 13 & Ferulic acid & $\mathrm{C}_{10} \mathrm{H}_{10} \mathrm{O}_{4}$ & $194.18 \mathrm{~g} / \mathrm{mol}$ & 0.10 & 3 & 4 & 2 & 51.63 & 66.76 & SOL & 1.36 \\
\hline 14 & $\begin{array}{l}\text { Protocatechuic } \\
\text { acid }\end{array}$ & $\mathrm{C}_{25} \mathrm{H}_{48} \mathrm{O}_{4}$ & $496.90 \mathrm{~g} / \mathrm{mol}$ & 0.72 & 10 & 4 & 0 & 146.41 & 44.76 & $\begin{array}{l}\text { Poorly } \\
\text { SOL }\end{array}$ & 6.36 \\
\hline 15 & Syringic acid & $\mathrm{C}_{9} \mathrm{H}_{10} \mathrm{O}_{5}$ & $198.17 \mathrm{~g} / \mathrm{mol}$ & 0.22 & 3 & 5 & 2 & 48.41 & 75.99 & V. SOL & 1.02 \\
\hline 16 & Gentisic acid & $\mathrm{C}_{7} \mathrm{H}_{6} \mathrm{O}_{4}$ & $154.12 \mathrm{~g} / \mathrm{mol}$ & 0.00 & 1 & 4 & 3 & 37.45 & 77.76 & SOL & 0.74 \\
\hline
\end{tabular}


Table 4. Cont.

\begin{tabular}{|c|c|c|c|c|c|c|c|c|c|c|c|}
\hline \multicolumn{12}{|c|}{ Physiochemical Properties } \\
\hline Sr. No. & Compound & Formula & MW & $\begin{array}{c}\text { Fraction } \\
\text { Csp3 }\end{array}$ & $\mathbf{R B}$ & HBA & HBD & MR & TPSA & ESOL & $\begin{array}{l}\text { Lipophilicity } \\
\text { Conseco Log } p\end{array}$ \\
\hline 17 & Vanillic acid & $\mathrm{C}_{8} \mathrm{H}_{8} \mathrm{O}_{4}$ & $168.15 \mathrm{~g} / \mathrm{mol}$ & 0.12 & 2 & 4 & 2 & 41.92 & 66.76 & SOL & 1.08 \\
\hline 18 & $p$-cumaric acid & $\mathrm{C}_{9} \mathrm{H}_{8} \mathrm{O}_{3}$ & $164.16 \mathrm{~g} / \mathrm{mol}$ & 0.00 & 2 & 3 & 2 & 45.13 & 57.53 & SOL & 1.26 \\
\hline 19 & Rutin & $\mathrm{C}_{27} \mathrm{H}_{30} \mathrm{O}_{16}$ & $610.52 \mathrm{~g} / \mathrm{mol}$ & 0.44 & 6 & 16 & 10 & 141.38 & 269.63 & SOL & -1.51 \\
\hline 20 & Flavan & $\mathrm{C}_{15} \mathrm{H}_{14} \mathrm{O}$ & $210.27 \mathrm{~g} / \mathrm{mol}$ & 0.2 & 1 & 1 & 0 & 65.08 & 29.24 & SOL & 3.47 \\
\hline
\end{tabular}

TPSA is another key parameter correlated with the drug's bioavailability. Passively absorbed compounds with high oral bioavailability have a TPSA $<140 \AA 2$ [23]. Table 4 shows that all the selected compounds are polar with TPSA values ranging from $29.46 \AA 2$ to $131.36 \AA 2$, except that chlorogenic acid and rutin had the highest TPSA (>140 A2), while the lowest TPSA was found for the compound flavan. High solubility can facilitate complete absorption in drug development schemes based on oral administration, and low solubility limits drug absorption in the gastrointestinal tract [27]. Table 4 shows that all 20 compounds have good to moderate water solubility, with a $\log S$ value between -1 and -5.6 and can promote good oral adsorption. Protocatechuic acid is poorly soluble with the bulky substituents. Marmelide, marmelon, alloimperatorin, and 6,7-epoxyauraptene are moderately soluble and the remainder are strongly soluble.

\subsubsection{Pharmacokinetics Properties}

The blood-brain barrier (BBB) permeation expresses the relative affinity of the drug for the blood or brain tissue. The compounds marmenol, caffeic acid, skimminianie, protocatechuic acid, rutin, and flavan are non-substrates of P-gp and are, therefore, required to induce phospholipidosis on the phenyl ring. The cytochrome P450 (CYP) superfamily is critical in drug removal through metabolic biotransformation [28]. The more negative the $\log \mathrm{Kp}(\mathrm{cm} / \mathrm{s})$ is, the less skin permeant the molecule is. It is found that the log $\mathrm{Kp}$ measurements of all the compounds evaluated are within the limits $(-8.0$ to -1.0$)$, except chlorogenic acid and rutinas shown in Table 5.

Table 5. Pharmacokinetics prediction of selected compounds of Aegle marmelos.

\begin{tabular}{|c|c|c|c|c|c|c|c|c|c|c|}
\hline \multicolumn{11}{|c|}{ Pharmacokinetics } \\
\hline Sr. No. & Compound & GIA & $\begin{array}{c}\text { BBB } \\
\mathbf{P}\end{array}$ & P-gpS & $\begin{array}{l}\text { CYP1A2 } \\
\text { Inhibitor }\end{array}$ & $\begin{array}{l}\text { CYP2C19 } \\
\text { Inhibitor }\end{array}$ & $\begin{array}{l}\text { CYP2C9 } \\
\text { Inhibitor }\end{array}$ & $\begin{array}{l}\text { CYP2D6 } \\
\text { Inhibitor }\end{array}$ & $\begin{array}{l}\text { CYP3A4 } \\
\text { Inhibitor }\end{array}$ & $\log K_{p}$ \\
\hline 1 & Marmelide & High & Yes & No & Yes & Yes & Yes & No & No & $\begin{array}{l}-5.46 \\
\mathrm{~cm} / \mathrm{s}\end{array}$ \\
\hline 2 & Marmenol & High & No & Yes & No & No & No & No & No & $\begin{array}{l}-7.05 \\
\mathrm{~cm} / \mathrm{s}\end{array}$ \\
\hline 3 & Scoparone & High & Yes & No & Yes & No & No & No & No & $\begin{array}{l}-6.34 \\
\mathrm{~cm} / \mathrm{s}\end{array}$ \\
\hline 4 & Scopoletin & High & Yes & No & Yes & No & No & No & No & $\begin{array}{l}-6.39 \\
\mathrm{~cm} / \mathrm{s} \\
\end{array}$ \\
\hline 5 & Alloimperatorin & High & Yes & No & Yes & Yes & Yes & Yes & Yes & $\begin{array}{l}-5.52 \\
\mathrm{~cm} / \mathrm{s}\end{array}$ \\
\hline 6 & $\begin{array}{c}6,7- \\
\text { epoxyauraptene }\end{array}$ & High & No & No & Yes & No & No & Yes & Yes & $\begin{array}{l}-7.05 \\
\mathrm{~cm} / \mathrm{s}\end{array}$ \\
\hline 7 & Caffeic acid & High & No & Yes & No & No & No & No & Yes & $\begin{array}{l}-7.82 \\
\mathrm{~cm} / \mathrm{s}\end{array}$ \\
\hline
\end{tabular}


Table 5. Cont.

\begin{tabular}{|c|c|c|c|c|c|c|c|c|c|c|}
\hline \multicolumn{11}{|c|}{ Pharmacokinetics } \\
\hline Sr. No. & Compound & GIA & $\begin{array}{c}\text { BBB } \\
\mathbf{P}\end{array}$ & P-gpS & $\begin{array}{l}\text { CYP1A2 } \\
\text { Inhibitor }\end{array}$ & $\begin{array}{l}\text { CYP2C19 } \\
\text { Inhibitor }\end{array}$ & $\begin{array}{l}\text { CYP2C9 } \\
\text { Inhibitor }\end{array}$ & $\begin{array}{l}\text { CYP2D6 } \\
\text { Inhibitor }\end{array}$ & $\begin{array}{l}\text { CYP3A4 } \\
\text { Inhibitor }\end{array}$ & $\log K_{p}$ \\
\hline 8 & Quercetin & High & Yes & No & Yes & Yes & Yes & Yes & Yes & $\begin{array}{l}-5.87 \\
\mathrm{~cm} / \mathrm{s}\end{array}$ \\
\hline 9 & Catechin & High & Yes & No & Yes & Yes & Yes & No & No & $\begin{array}{l}-5.46 \\
\mathrm{~cm} / \mathrm{s}\end{array}$ \\
\hline 10 & Skimmianine & High & No & Yes & No & No & No & No & No & $\begin{array}{l}-7.05 \\
\mathrm{~cm} / \mathrm{s}\end{array}$ \\
\hline 11 & $\begin{array}{l}\text { Chlorogenic } \\
\text { acid }\end{array}$ & Low & No & No & No & No & No & No & No & $\begin{array}{l}-8.76 \\
\mathrm{~cm} / \mathrm{s}\end{array}$ \\
\hline 12 & Gallic acid & High & No & No & No & No & No & No & Yes & $\begin{array}{l}-6.84 \\
\mathrm{~cm} / \mathrm{s}\end{array}$ \\
\hline 13 & Ferulic acid & High & Yes & No & No & No & No & No & No & $\begin{array}{l}-6.41 \\
\mathrm{~cm} / \mathrm{s}\end{array}$ \\
\hline 14 & $\begin{array}{l}\text { Protocatechuic } \\
\text { acid }\end{array}$ & Low & No & Yes & No & No & No & No & No & $\begin{array}{l}-2.19 \\
\mathrm{~cm} / \mathrm{s}\end{array}$ \\
\hline 15 & Syringic acid & High & No & No & No & No & No & No & No & $\begin{array}{l}-6.77 \\
\mathrm{~cm} / \mathrm{s}\end{array}$ \\
\hline 16 & Gentisic acid & High & No & No & No & No & No & No & Yes & $\begin{array}{l}-6.00 \\
\mathrm{~cm} / \mathrm{s}\end{array}$ \\
\hline 17 & Vanillic acid & High & No & No & No & No & No & No & No & $\begin{array}{l}-6.31 \\
\mathrm{~cm} / \mathrm{s}\end{array}$ \\
\hline 18 & $\begin{array}{l}\text { P-cumaric } \\
\text { acid }\end{array}$ & High & Yes & No & No & No & No & No & No & $\begin{array}{l}-6.26 \\
\mathrm{~cm} / \mathrm{s}\end{array}$ \\
\hline 19 & Rutin & Low & No & Yes & No & No & No & No & No & $\begin{array}{c}-10.26 \\
\mathrm{~cm} / \mathrm{s}\end{array}$ \\
\hline 20 & Flavan & High & Yes & Yes & Yes & Yes & Yes & Yes & No & $\begin{array}{l}-4.88 \\
\mathrm{~cm} / \mathrm{s}\end{array}$ \\
\hline
\end{tabular}

\subsubsection{Lipophilicity and Drug-likeness}

Table 6 shows that the $\log p$ values of all the compounds of the designed compounds were in the library, except protocatechuic acid $(\log p=6.36)$. It was found to be within the limits, i.e., between -0.7 and +5.0 , and thus, good permeability and oral absorption are expected. Drug-likeness qualitatively tests a molecule's likelihood of being an oral drug candidate with respect to bioavailability $[29,30]$.

Table 6. Drug-likeness and medicinal chemistry properties of selected compounds of A. marmelos.

\begin{tabular}{|c|c|c|c|c|c|c|c|c|c|c|}
\hline \multicolumn{8}{|c|}{ Drug Likeness } & \multicolumn{3}{|c|}{ Medicinal Chemistry } \\
\hline Sr. No. & Compound & Lipinski & Ghose & Veber & Egen & Muegge & BAS & PAINS & $\begin{array}{c}\text { Lead } \\
\text { Likeness }\end{array}$ & SA \\
\hline 1. & Marmelide & Yes & Yes & Yes & Yes & Yes & 0.55 & 0 alert & Yes & 3.22 \\
\hline 2 & Marmenol & Yes & Yes & Yes & Yes & Yes & 0.55 & 0 alert & No; 1 & 4.33 \\
\hline 3 & Scoparone & Yes & Yes & Yes & Yes & Yes & 0.55 & 0 alert & $\begin{array}{c}\text { No; } 1 \\
\text { violation }\end{array}$ & 2.77 \\
\hline 4 & Scopoletin & Yes & Yes & Yes & Yes & $\begin{array}{c}\text { No; } 1 \\
\text { violation }\end{array}$ & 0.55 & 0 alert & $\begin{array}{c}\text { No; } 1 \\
\text { violation }\end{array}$ & 2.62 \\
\hline 5 & $\begin{array}{c}6,7- \\
\text { epoxyauraptene }\end{array}$ & Yes & Yes & Yes & Yes & Yes & 0.55 & 0 alert & $\begin{array}{c}\text { No; } 1 \\
\text { violation }\end{array}$ & 3.92 \\
\hline 6 & Quercetin & Yes & Yes & Yes & Yes & Yes & 0.55 & 1 alert & yes & 3.23 \\
\hline 7 & Catechin & Yes & Yes & Yes & Yes & Yes & 0.55 & 1 alert & yes & 3.50 \\
\hline 8 & Skimmianine & Yes & Yes & Yes & Yes & Yes & 0.55 & 0 alert & yes & 2.93 \\
\hline 9 & Alloimperatorin & & & & & & 0.5 & 0 alert & $\mathrm{No}$ & 3.2 \\
\hline
\end{tabular}


Table 6. Cont.

\begin{tabular}{|c|c|c|c|c|c|c|c|c|c|c|}
\hline \multicolumn{8}{|c|}{ Drug Likeness } & \multicolumn{3}{|c|}{ Medicinal Chemistry } \\
\hline Sr. No. & Compound & Lipinski & Ghose & Veber & Egen & Muegge & BAS & PAINS & $\begin{array}{c}\text { Lead } \\
\text { Likeness }\end{array}$ & SA \\
\hline 10 & $\begin{array}{l}\text { Chlorogenic } \\
\text { acid * }\end{array}$ & Yes & $\begin{array}{c}\text { No; } 1 \\
\text { violation }\end{array}$ & $\begin{array}{c}\text { No; } 1 \\
\text { violation }\end{array}$ & No & No & 0.11 & 1 alert & No & 4.16 \\
\hline 11 & Gallic acid * & Yes & $\begin{array}{c}\text { No; } 2 \\
\text { violations }\end{array}$ & Yes & Yes & $\begin{array}{c}\text { No; } 1 \\
\text { violation }\end{array}$ & 0.56 & 1 alert & No & 1.22 \\
\hline 12 & Ferulic acid & Yes & Yes & Yes & Yes & $\begin{array}{c}\text { No; } 1 \\
\text { violation }\end{array}$ & 0.85 & 0 alert & No & 1.93 \\
\hline 13 & $\begin{array}{l}\text { Protocatechuic } \\
\text { acid }\end{array}$ & Yes & No & $\begin{array}{c}\text { Yes; } 4 \\
\text { violations }\end{array}$ & $\begin{array}{c}\text { No; } 1 \\
\text { violation }\end{array}$ & $\begin{array}{c}\text { No; } 1 \\
\text { violation }\end{array}$ & 0.55 & 0 alert & $\begin{array}{c}\text { No;3 } \\
\text { violation }\end{array}$ & 5.09 \\
\hline 14 & Syringic acid & Yes & Yes & Yes & Yes & $\begin{array}{c}\text { No; } 1 \\
\text { violation }\end{array}$ & 0.56 & 0 alert & $\begin{array}{c}\text { No; } 1 \\
\text { violation }\end{array}$ & 1.70 \\
\hline 15 & Gentisic acid * & Yes & $\begin{array}{c}\text { No; } 3 \\
\text { violations }\end{array}$ & Yes & Yes & $\begin{array}{c}\text { No; } 1 \\
\text { violations }\end{array}$ & 0.56 & 0 alert & $\begin{array}{c}\text { No; } 1 \\
\text { violation }\end{array}$ & 1.10 \\
\hline 16 & Vanillic acid & Yes & Yes & Yes & Yes & $\begin{array}{c}\text { No; } 1 \\
\text { violation }\end{array}$ & 0.84 & 0 alert & $\begin{array}{c}\text { No; } 1 \\
\text { violation }\end{array}$ & 1.42 \\
\hline 17 & $\begin{array}{l}\text { p-cumaric } \\
\text { acid }\end{array}$ & Yes & Yes & Yes & Yes & $\begin{array}{c}\text { No; } 1 \\
\text { violation }\end{array}$ & 0.85 & 0 alert & $\begin{array}{c}\text { No; } 1 \\
\text { violation }\end{array}$ & 1.61 \\
\hline 18 & Rutin * & $\begin{array}{c}\text { No; } 3 \\
\text { violations }\end{array}$ & $\begin{array}{c}\text { No; } 4 \\
\text { violations }\end{array}$ & $\begin{array}{c}\text { No; } 1 \\
\text { violation }\end{array}$ & $\begin{array}{c}\text { No; } 1 \\
\text { violation }\end{array}$ & $\begin{array}{c}\text { No; } 4 \\
\text { violations }\end{array}$ & 0.17 & 1 alert & $\begin{array}{c}\text { No; } 1 \\
\text { violation }\end{array}$ & \\
\hline 19 & Flavan & Yes & Yes & Yes & Yes & $\begin{array}{c}\text { No; } 1 \\
\text { violation }\end{array}$ & 0.55 & 0 alert & $\begin{array}{c}\text { No; } 2 \\
\text { violation }\end{array}$ & 2.70 \\
\hline 20 & Caffeic acid & Yes & Yes & Yes & Yes & $\begin{array}{c}\text { No; } 1 \\
\text { violation }\end{array}$ & 0.56 & 1 alert & $\begin{array}{c}\text { No; } 1 \\
\text { violation }\end{array}$ & 1.81 \\
\hline
\end{tabular}

* Not satisfying either two of the Lipinski, Ghose, and Veber drug likeness rules, BAS = Bioavailability score $\leq 0.55$, SA = Synthetic accessibility.

\subsubsection{Rule-of-Five by Lipinski}

As per Lipinski's rule-of-five [3], it is likely to be produced as a prospective oral drug if it violates none or less than one of the following four conditions. In this investigation, 12 out of the 20 selected compounds did not pass the ADME screening, leaving eight candidate compounds for the molecular docking analysis (Tables 4-6), thus demonstrating the potential usefulness of the series for drug-like compound growth.

\subsubsection{Medicinal Chemistry}

PAINS are substances with sub-structures that display a false reaction, irrespective of the protein receptor, with biologically potent output [31]. Table 6 shows that thirteen compounds returned any PAINS alert. For all the candidates in the library, the SA scores were found to be less than four and, thus, have an excellent synthesis feasibility. The score of synthetic accessibility (SA) is normalized between 1 (easy synthesis) and 10 (very difficult synthesis). For most candidates in the library, the SA scores were found to be less than four and, thus, have a strong synthesis feasibility.

The lead-like rule-based approach lets the medicinal chemist define the required molecule to start lead optimization. Table 6 indicates that the marmelide, quercetin, catechin, and skimminianie exhibit zero violations of lead-likeness, and are, therefore, appropriate for initiating lead optimization. Furthermore, as is evident from the radar depictions, 13 compounds with one violation are also found to meet the requirement for oral bioavailability.

\subsubsection{Bioavailability Radar}

From the bioavailability radar, the drug-likeness of a molecule can be rapidly measured. The pink colored region is the required physiochemical space for oral bioavailability and the molecule's radar plot must fall entirely into the field to be considered drug-like [32]. It is evident from the Swiss ADME prediction performance that eight compounds have 
the optimal range of all six properties, allowing them to be considered to have proficient chemotherapeutic potential (Figure 3).

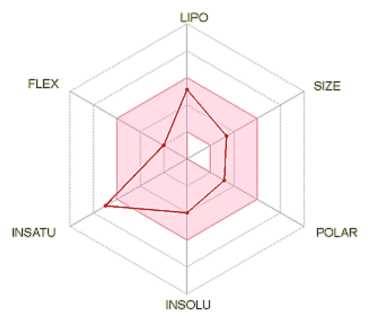

(a)

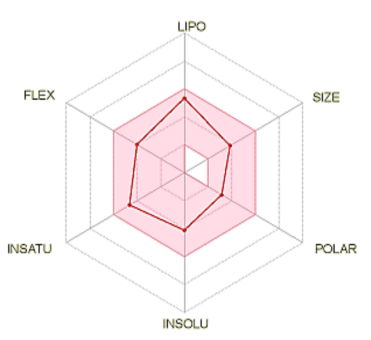

(e)

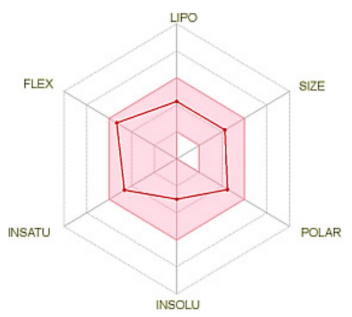

(b)

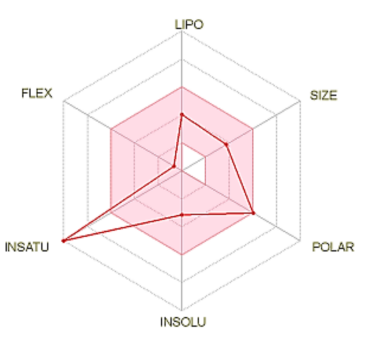

$(\mathbf{f})$

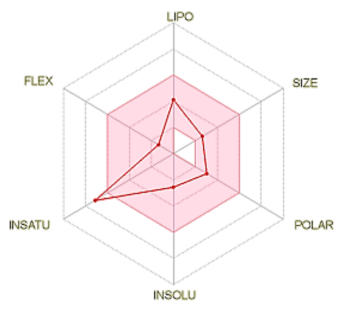

(c)

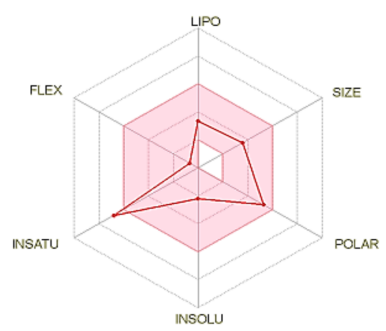

(g)

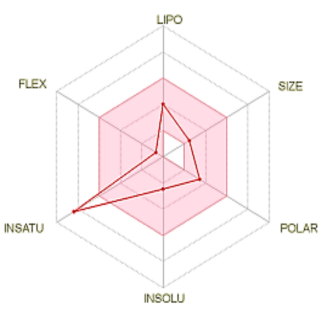

(d)

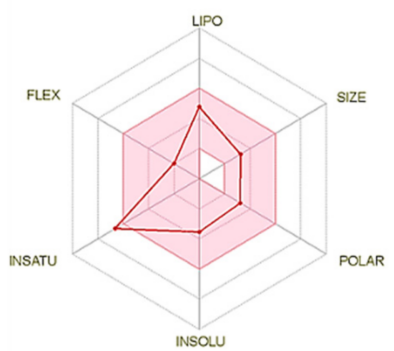

(h)

Figure 3. Bioavailability radar (pink area exhibits optimal range of particular property) for studied compounds (LIPO = lipophilicity as XLOGP3; SIZE = size as molecular weight; POLAR = polarity as TPSA (topological polar surface area); INSOLU = insolubility in water by $\log \mathrm{S}$ scale; INSATU = instauration as per fraction of carbons in the sp3 hybridization and FLEX = flexibility as per rotatable bonds). $(\mathbf{a})=$ Marmelide,$(\mathbf{b})=$ Marmenol,$(\mathbf{c})=$ Scoparone,$(\mathbf{d})=$ Scopoletin,$(\mathbf{e})=6^{\prime}$, $7^{\prime}$-epoxyauraptene, $(\mathbf{f})=$ Quercetin, $(\mathbf{g})=$ Catechin, $(\mathbf{h})=$ Skimmianine.

\subsection{Molecular Docking Analysis}

After selecting the eight compounds using the Swiss ADME, chem-draw ultra 12.0 and chem 3D pro were used in GOLD docking for the energy minimization of ligands. The molecular docking research examined the molecular interactions of these compounds with the HN protein, which is the primary pathogenic factor, in order to understand the antiviral potency of the selected compounds. The coordinate crystal structure of the HN protein was obtained from the protein data bank (PDB). Then, this structure was loaded into GOLD suite version 5.3.0 with a resolution of 2.70 $\AA$ for docking. The screenings of various dock complexes have been conducted using the GOLD 5.3.0 version on the basis of docking fitness and GOLD score. The GOLD program resulted in the best compound interacting with the receptor being found. The findings were assessed on the basis of binding compatibility, i.e., docking score and fitness. As a best drug, the ligand molecule that displayed the highest binding affinity to the receptor molecule was chosen.

Based on the number of hydrogen bonds formed and the bond distance between the atomic coordinates of the active site and the inhibitor, the final docked conformation obtained for the candidate compounds was assessed. Table 7 provides the GOLD docking scores for the phytochemical compounds. Each docking routine returned top ten ranked docked poses for each ligand. The compounds with the maximum ligand-receptor binding energy and interactions with the receptor ( $<6 \AA$ bond lengths) were predicted to be the most effective. Table 7 shows that the best GOLD fitness and GOLD score was shown by the docked conformers of the synthesized three compounds. 
Table 7. Docking interactions of selected bioactive compounds of A. marmelos.

\begin{tabular}{|c|c|c|c|c|c|c|c|c|c|c|}
\hline $\begin{array}{l}\text { Sr. } \\
\text { No. }\end{array}$ & Compound & PubChem ID & 2D Structure & Gold Score & $\begin{array}{l}\text { Gold Binding } \\
\text { Fitness }\end{array}$ & RMSD & Residue & Hydrophobicity & Pka & Distance \\
\hline \multirow{10}{*}{1.} & \multirow{10}{*}{ Marmelide } & \multirow{10}{*}{10,212} & & \multirow{10}{*}{-4.09} & \multirow{10}{*}{51.99} & \multirow{10}{*}{86.95} & ARG51 & -4.5 & 12 & 2.26 \\
\hline & & & & & & & ILE52 & 4.5 & & 5.46 \\
\hline & & & & & & & GLU135 & -3.5 & 4.3 & 4.41 \\
\hline & & & & & & & TYR176 & -1.3 & 10 & 5.43 \\
\hline & & & & & & & TYR194 & -1.3 & 10 & 2.67 \\
\hline & & & & & & & GLY279 & -3.5 & 4.3 & \\
\hline & & & & & & & ARG293 & -4.5 & 12 & 2.44 \\
\hline & & & & & & & VAL343 & 4.2 & & 4.73 \\
\hline & & & & & & & ARG375 & -4.5 & 12 & 2.22 \\
\hline & & & & & & & TYR403 & -1.3 & 10 & 2.49 \\
\hline \multirow{9}{*}{2.} & \multirow{9}{*}{ Marmenol } & \multirow{9}{*}{$129,847,759$} & & \multirow{9}{*}{-2.20} & \multirow{9}{*}{55.66} & \multirow{9}{*}{86.39} & ARG51 & -4.5 & 12 & 2.46 \\
\hline & & & & & & & LYS113 & -3.9 & 10.4 & 4.69 \\
\hline & & & & & & & TYR194 & -1.3 & 10 & 3.27 \\
\hline & & & & & & & ARG240 & -4.5 & 12 & 4.72 \\
\hline & & & & & & & GLY276 & -0.4 & & 2.53 \\
\hline & & & & & & & ALA277 & 1.8 & & 2.29 \\
\hline & & & & & & & ARG293 & -4.5 & 12 & 2.98 \\
\hline & & & & & & & SER295 & -0.8 & & 1.69 \\
\hline & & & & & & & VAL343 & 4.2 & & 4.71 \\
\hline \multirow{8}{*}{3.} & \multirow{8}{*}{ Scoparone } & \multirow{8}{*}{8417} & & \multirow{8}{*}{-0.04} & \multirow{8}{*}{45.00} & \multirow{8}{*}{85.77} & ARG51 & -4.5 & 12 & 2.30 \\
\hline & & & & & & & GLU135 & -3.5 & 4.3 & 4.83 \\
\hline & & & & & & & TYR176 & -1.3 & 10 & 4.69 \\
\hline & & & & & & & TYR194 & -1.3 & 10 & 5.26 \\
\hline & & & & & & & GLU278 & -3.5 & 4.3 & 3.89 \\
\hline & & & & & & & ARG293 & -4.5 & 12 & 2.01 \\
\hline & & & & & & & ARG375 & -4.5 & 12 & 2.62 \\
\hline & & & & & & & TYR403 & -1.3 & 10 & 2.36 \\
\hline
\end{tabular}


Table 7. Cont.

\begin{tabular}{|c|c|c|c|c|c|c|c|c|c|c|}
\hline $\begin{array}{l}\text { Sr. } \\
\text { No. }\end{array}$ & Compound & PubChem ID & 2D Structure & Gold Score & $\begin{array}{l}\text { Gold Binding } \\
\text { Fitness }\end{array}$ & RMSD & Residue & Hydrophobicity & Pka & Distance \\
\hline \multirow{9}{*}{4.} & \multirow{9}{*}{ Scopoletin } & \multirow{9}{*}{$5,280,460$} & & \multirow{9}{*}{-1.22} & \multirow{9}{*}{47.61} & & ARG51 & -4.5 & 12 & 2.26 \\
\hline & & & & & & & SER114 & -0.8 & & 2.25 \\
\hline & & & & & & & GLU135 & -3.5 & 4.3 & 4.71 \\
\hline & & & & & & & TYR176 & -1.3 & 10 & 4.60 \\
\hline & & & & & & & TYR194 & -1.3 & 10 & 1.83 \\
\hline & & & & & & & GLU278 & -3.5 & 4.3 & 3.84 \\
\hline & & & & & & & ARG293 & -4.5 & 12 & 2.14 \\
\hline & & & & & & & ARG375 & -4.5 & 12 & 2.66 \\
\hline & & & & & & & TYR403 & -1.3 & 10 & 2.35 \\
\hline \multirow{9}{*}{5.} & \multirow{9}{*}{$\begin{array}{c}6,7- \\
\text { epoxyauraptene }\end{array}$} & \multirow{9}{*}{$9,796,891$} & & \multirow{9}{*}{-3.71} & \multirow{9}{*}{49.48} & \multirow{9}{*}{84.90} & ILE52 & 4.5 & & 4.88 \\
\hline & & & & & & & HIS76 & -3.2 & 6 & 4.19 \\
\hline & & & & & & & LYS113 & -3.9 & 10.4 & 4.73 \\
\hline & & & & & & & GLU135 & -3.5 & 4.3 & \\
\hline & & & & & & & TYR176 & -1.3 & 10 & 4.93 \\
\hline & & & & & & & TYR194 & -1.3 & 10 & 4.97 \\
\hline & & & & & & & MET275 & 1.9 & & 5.73 \\
\hline & & & & & & & ALA277 & 1.8 & & 4.78 \\
\hline & & & & & & & VAL343 & 4.2 & & 4.59 \\
\hline \multirow{9}{*}{6.} & \multirow{9}{*}{ Quercetin } & \multirow{9}{*}{$5,280,343$} & & \multirow{9}{*}{-8.25} & \multirow{9}{*}{56.91} & \multirow{9}{*}{85.25} & ARG51 & -4.5 & 12 & 2.22 \\
\hline & & & & & & & GLU135 & -3.5 & 4.3 & 1.75 \\
\hline & & & & & & & TYR139 & -1.3 & 10 & 1.88 \\
\hline & & & & & & & TYR194 & -1.3 & 10 & 3.04 \\
\hline & & & & & & & GLU278 & -3.5 & 4.3 & 4.37 \\
\hline & & & $\mathrm{OH} \mathrm{O}$ & & & & ARG293 & -4.5 & 12 & 1.89 \\
\hline & & & & & & & VAL343 & 4.2 & & 5.11 \\
\hline & & & & & & & ARG375 & -4.5 & 12 & 2.38 \\
\hline & & & & & & & TYR403 & -1.3 & 10 & 2.13 \\
\hline
\end{tabular}


Table 7. Cont.

\begin{tabular}{|c|c|c|c|c|c|c|c|c|c|c|}
\hline $\begin{array}{l}\text { Sr. } \\
\text { No. }\end{array}$ & Compound & PubChem ID & 2D Structure & Gold Score & $\begin{array}{l}\text { Gold Binding } \\
\text { Fitness }\end{array}$ & RMSD & Residue & Hydrophobicity & Pka & Distance \\
\hline \multirow{11}{*}{7.} & \multirow{11}{*}{ Catechin } & \multirow{11}{*}{9064} & & \multirow{11}{*}{-4.44} & \multirow{11}{*}{52.92} & \multirow{11}{*}{83.67} & ARG51 & -4.5 & 12 & 2.80 \\
\hline & & & & & & & GLU135 & -3.5 & 4.3 & 1.86 \\
\hline & & & & & & & TYR194 & -1.3 & 10 & 3.05 \\
\hline & & & & & & & ARG240 & -4.5 & 12 & 2.29 \\
\hline & & & & & & & GLY276 & -0.4 & & 2.76 \\
\hline & & & & & & & ALA277 & 1.8 & & 5.31 \\
\hline & & & & & & & ARG293 & -4.5 & 12 & 4.20 \\
\hline & & & & & & & SER295 & -0.8 & & 2.23 \\
\hline & & & & & & & VAL343 & 4.2 & & 5.44 \\
\hline & & & & & & & ARG375 & -4.5 & 12 & 3.70 \\
\hline & & & & & & & TYR403 & -1.3 & 10 & 1.88 \\
\hline \multirow{8}{*}{8.} & \multirow{8}{*}{ Skimminianie } & \multirow{8}{*}{6760} & & \multirow{8}{*}{-22.68} & \multirow{8}{*}{43.28} & \multirow{8}{*}{85.42} & ILES52 & 4.5 & & 4.26 \\
\hline & & & & & & & GLU135 & -3.5 & 4.3 & 4.72 \\
\hline & & & & & & & TYR194 & -1.3 & 10 & 5.20 \\
\hline & & & & & & & ARG240 & -4.5 & 12 & 3.54 \\
\hline & & & & & & & GLU278 & -3.5 & 4.3 & 4.53 \\
\hline & & & & & & & ARG293 & -4.5 & 12 & 3.33 \\
\hline & & & & & & & VAL343 & 4.2 & & 2.94 \\
\hline & & & & & & & TYR403 & -1.3 & 10 & 5.34 \\
\hline
\end{tabular}


Quercetin, catechin, and marmenol showed the best interaction with the HN protein, having GOLD fitness of 56.91, 55.66, and 52.92, and GOLD docking scores of $-8.25,-4.44$, and -2.20 , including forming a hydrogen bond (TYR A:139, TYR A:194, ARG A:293, ARG A:375, and ARG A:51; ARG A:293, ARG A:240, ARG A:375, TYR A:194, and TYR A:139; ARG A:375, and TYR A:194), respectively. These compounds showed an exceptionally good interaction with the $\mathrm{HN}$ protein and can be considered as potential molecules that may prove to be beneficial in antiviral activity through their direct action on NDV. Marmelide, $6^{\prime}, 7$-epoxyauraptene, scopoletin, and scoparone showed moderate binding affinity having GOLD fitness of 51.99, 49.48, 47.61, and 50.00, GOLD docking score of $-4.09,-3.71,-1.22$, and -0.04 , and having an interaction of the hydrogen bond with (ARG A:51, ARG A:375, ARG A:293 and ARG A:51; ARG A:293, ARG A:375, TYR A:194, and ARG A:51; ARG A:293, ARG A:375, TYR A:194, GLU A:135, and SER A:114). Epoxyauraptene has a hydrophobic interaction. Skimminianie/4,7,8-trimethoxyfuroquinoline has the lowest interaction, in the range of 43.46 , and a docking score of -22.68 .

Figure 4 shows a 2D view of the protein-ligand interactions of the best poses produced by the discovery studio. All the molecules possess the same binding mode, as clearly shown in Figure 4. Interestingly, the major interactions between these atoms can be identified and the residues are ARG A:51, ARG A:293, ARG A:375, and TYR A:194. 

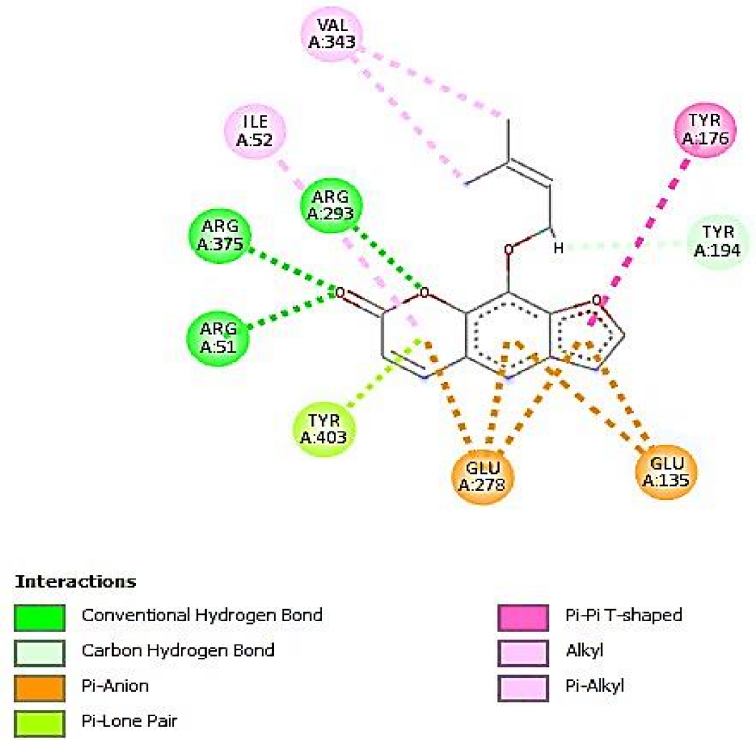

(a)

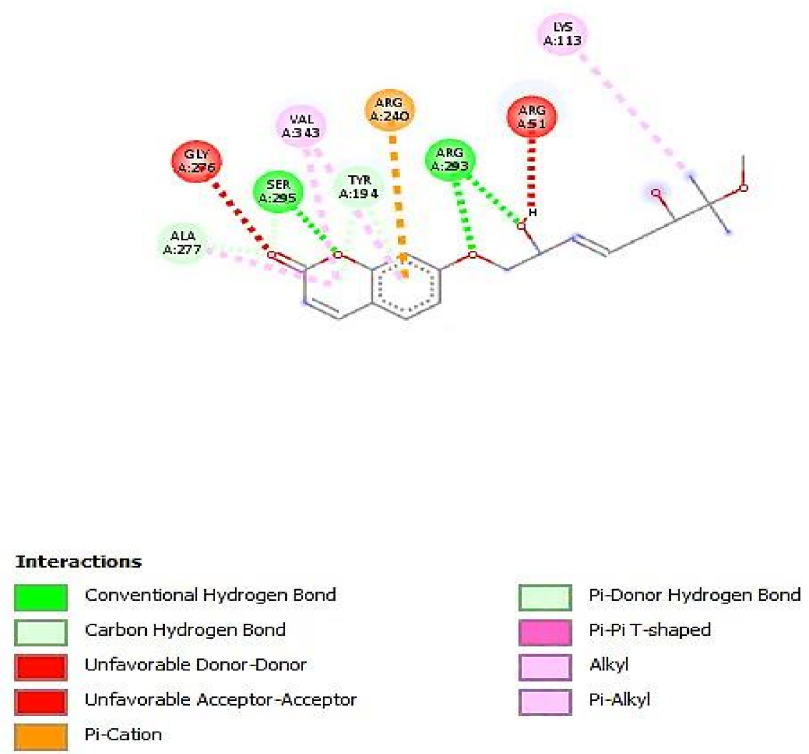

(b)

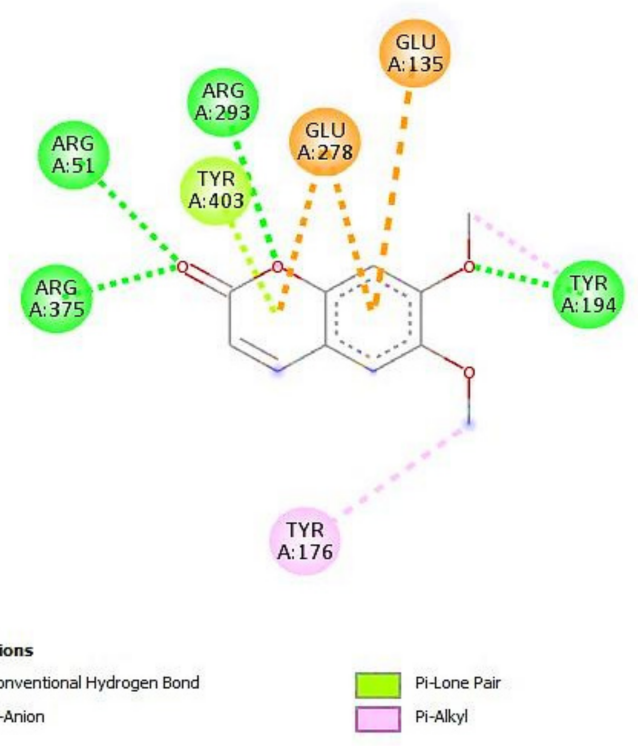

(c)

Figure 4. Cont. 


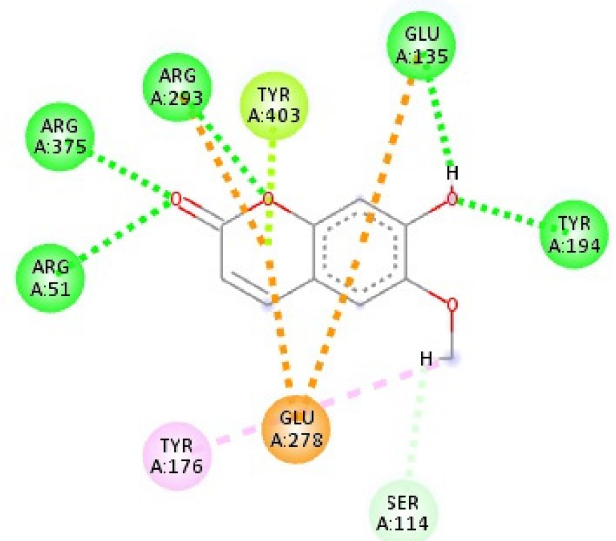

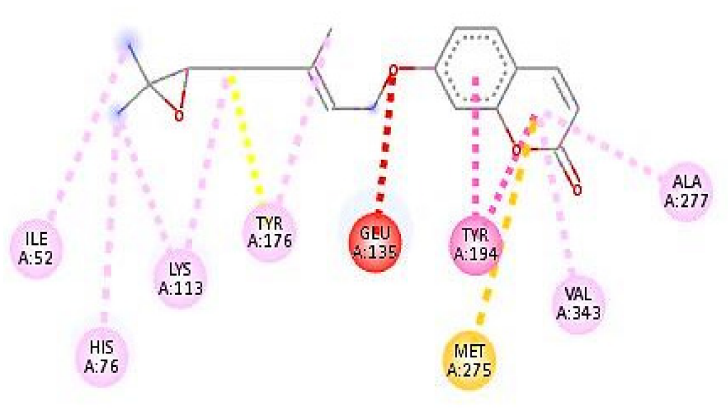

Interactions

$\square$ Unfavorable Acceptor-Acceptor
$\square$ Pi-Sulfur
$\square$ Pi-PiT-shaped

(d)

Pi-Anion
$\square$ Pi-Lone Pair
$\square$ Pi-Alkyl

(e)

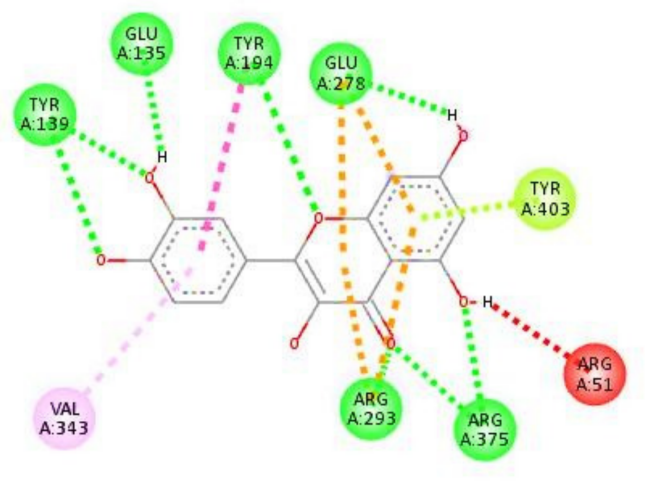

Interactions

Conventional Hydrogen Bond

Unfavorable Donor-Donor
Pi-Cation

Pi-Anion

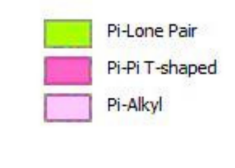

(f)

Figure 4. Cont. 

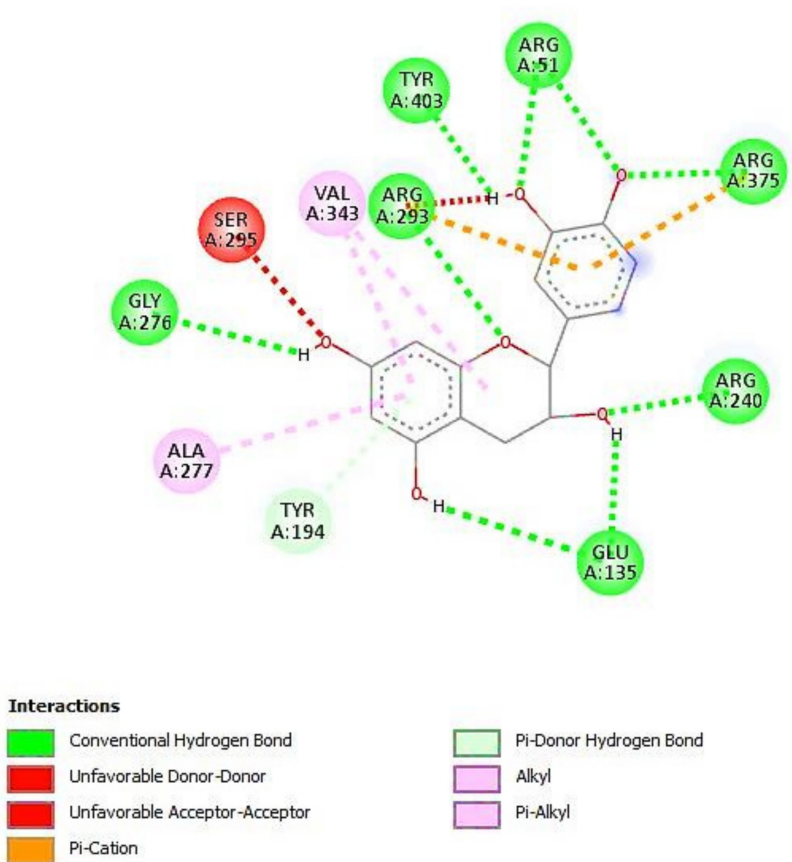

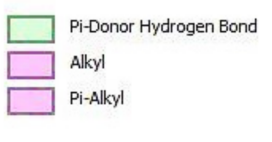

$(\mathbf{g})$

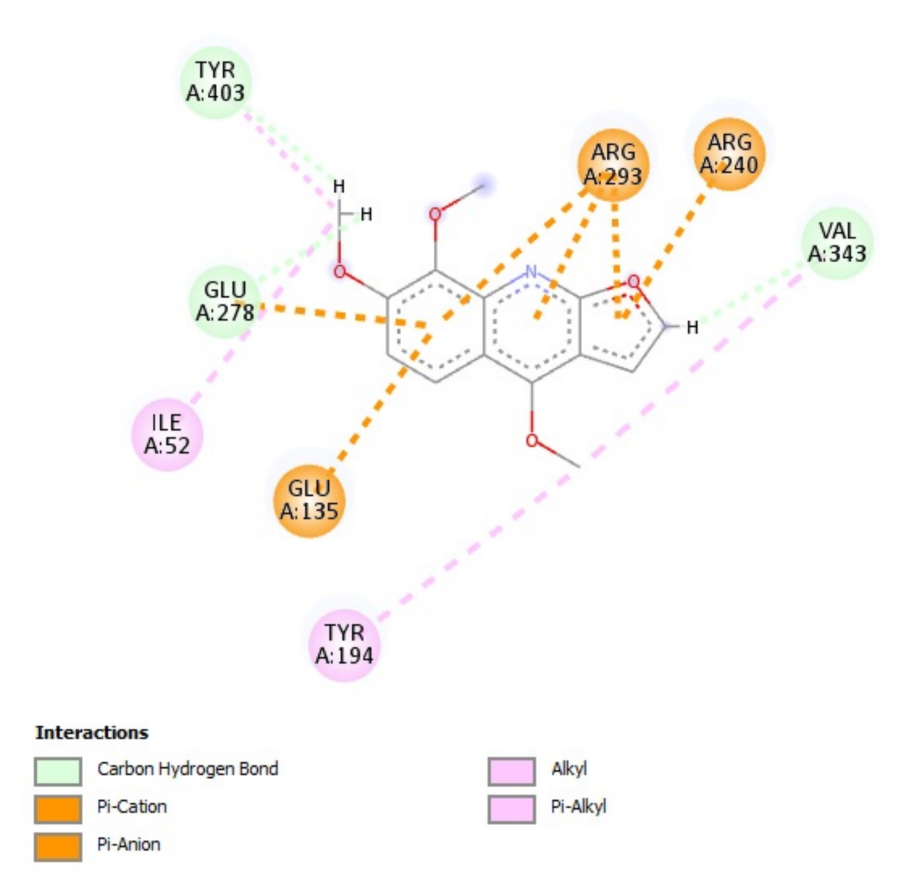

(h)

Figure 4. In silico molecular docking results of interactions between HN protein with screened compounds as ligand. $(\mathbf{a})=$ Marmelide, $(\mathbf{b})=$ Marmenol, $(\mathbf{c})=$ Scoparone, $(\mathbf{d})=$ Scopoliten, $(\mathbf{e})=6^{\prime} 7^{\prime}$-epoxyaraptene, $(\mathbf{f})=$ Quercetin, $(\mathbf{g})=$ Catechin, $(\mathbf{h})=$ Skimminianie. 


\section{Discussion}

The medicinal qualities of economically important plants are attributed to the presence of certain beneficial elements in them. The present study supports the health benefits associated with $A$. marmelos correlated with the presence of phenolic and flavonoid compounds in its leaves and fruit [33]. The current study indicates that the fruit extract has higher contents of TPC and TFC than the leaves. The total phenolic contents (TPC) and the total flavonoids contents (TFC) are litmus tests for the antioxidant potential of any plant extract. A significantly high TPC and TFC suggests that $A$. marmelos extract has substantial antioxidant potential, which was verified using two typically known techniques of DPPH and ferric-reducing power analysis. Our results are in accordance with the study of Barkatullah et al. [18], where the TPC value of ethanolic extracts of Z. armatum fruits was found to be $21.68 \pm 0.44 \mathrm{mg} / \mathrm{g}$ and that of the bark was $16.48 \pm 1.33 \mathrm{mg} / \mathrm{g}$. The phenolic content of any plant is directly related to its antioxidant potential. Phenolic compounds act as reducing agents, hydrogen donors, and are capable of scavenging free radicals [24]. The presence of a considerably good quantity of phenolics in the fruit and leaves extracts of $A$. marmelos may contribute significantly to the antioxidant properties. Due to these properties, this plant has been used in several traditional herbal medications.

The values of TPC, TFC, and antioxidant potentials in this current study could vary compared to those in the literature. This may be due to the study of difference in the ability of the studied parts, the solvent, or the methods of extraction, which may alter the amount of phytocomponents in them, which are responsible for valuable activities.

The results suggested that the plant extracts contain phytochemical constituents that are capable of donating hydrogen to a free radical to scavenge the potential damage. Therefore, these findings are comparable with those in the literature for other extracts of plant products [34]. The graphical presentations illustrated that both extracts showed the significant scavenging activity of the free radicals in a concentration-dependent manner; an improvement in the antioxidant potential has been observed with an increase in the phenolic and flavonoid components.

The results of the biofilm inhibition assays were in accordance with Sánchez et al. [35] and Eduardo et al. [36], who stated that methanolic caper extract significantly inhibited the growth of biofilm and ESP in P. aeruginosa, E. coli, S. marcescens, and three separate species, Gutierrezia microcephala, Prosopis laevigata, and Opuntia ficus-indica. Similarly, other studies showed that the crude extracts from Juglans regia L. and Mangifera indica L. potentially inhibited the formation of biofilm in P. aeruginosa [37].

The present research revealed the antiviral potential using an in ovo technique against $N D V$ using leaves and fruit extracts from $A$. marmelos. In this analysis, the 2 days postinoculation clearly showed the highly virulent nature of the virus strain because of the death of all the chicken embryos. The results corroborate the findings of Ashraf et al. [38], where the methanolic extract of the leaves of Glycyrrhiza glabra at $300 \mu \mathrm{g} / \mathrm{mL}$ exhibited a strong antiviral activity against $N D V$ in vivo. Similarly, the plant extracts effectively control the virus, as no viruses were identified in the allantoic fluids. The findings of Okoroafor et al. [39] suggested that the methanolic stem bark extract of Azadihiracta indica significantly affected the weight, hematology, and immunology of vaccinated chickens.

The observed antiviral activity can be due to the existence and elucidation of the bioactive elements. The major compound that may be responsible for the antiviral activity has not been identified. A. marmelos fruit has marmelide and tannins, which are reported for antiviral activity in the initial stages of virus growth [38]. The strong antiviral activity of both parts of $A$. marmelos against $N D V$ is beneficial for managing $N D$ in other avian species.

Based on the result obtained from TPC, TFC, antioxidant measures, biofilm inhibition activity as well as the anti-viral activity checked using an in ovo technique, the methanolic fruit extract of $A$. marmelos, has a higher medicinal potential than the leaves. This study could be a baseline for larger and further research into tapping the antiviral potentials of this plant. This study gives recommendations of an in vivo study using live chickens that could possibly further accommodate the efficacy of the plant extract on anti-viral activity. 
From the point of view of drug development, the drug-like, bioavailability, and pharmacokinetics abilities are more important parameters to predict the molecule for the investigation of successful potential drug molecules. In the clinical trial stage or later, too many potent medicines fail in the drug development phase because of its weak abilities. In the present study, before performing molecular docking, all the compounds were subjected to ADME to ensure the drug-like characteristics of the bioactive compounds of $A$. marmelos.

With the exception of three compounds (Table 5), all were observed with high intestinal absorption and could, thus, penetrate very easily through the intestinal lining and access the cell membrane. To meet their molecular target, the drugs that function in the central nervous system (CNS) need to move through the blood-brain barrier (BBB). However, for drug molecules with a peripheral target, little to no BBB permeation may be needed to prevent side effects of the central nervous system [39]. Table 5 indicates that 12 compounds are estimated to have no penetration of the blood-brain barrier, and thus the chance of CNS side effects is expected to be absent. P-glycoprotein (P-gp) plays a significant role in protecting the central nervous system from xenobiotics [40]. The predicted outcome shows that most of the compounds are P-gp substrates and do not cause phospholipidosis. The abbot bioavailability score (BAS) is a rule-based semi-quantitative score that relies on total charge, TPSA, and the five rules of Lipinski filter violation that distinguishes four compound groups. All of the selected molecules have a bioavailability score of 0.55 , except for P-cumaric acid and ferulic acid, indicating a chance of becoming an oral drug candidate [29].

In the virtual screening of drug-like compounds, molecular docking has become an important computational approach. In the current study, one of the major glycoproteins, hemagglutinin-neuraminidase $(\mathrm{HN})$, of $N D V$ was docked with the eight candidate compounds to find out the most favorable interacting complexes.

An important method for the prediction of the binding ability of active biological constituents against selected proteins is the computational molecular-docking analysis. The binding energy was influenced by multiple forms of interaction [41]. Hydrogen bonds are important contributors to the protein-protein or ligand-receptor structure and interaction [42]. To endorse the findings of this study, a molecular-docking study was performed, where quercetin, catechin, and marmenol showed excellent interaction with the HN protein by having GOLD fitness of (56.91, 55.66, and 52.92), GOLD docking scores of $(-8.25$, -4.44 , and -2.20$)$, and forming a hydrogen bond with amino acid residues. Marmelide, 6'7-epoxyauraptene, scopoletin, and scoparone showed moderate binding affinity (51.99, $49.48,47.61,50.00)$ and GOLD docking scores $(-4.09,-3.71,-1.22,-0.04)$. Skimminianie showed the least affinity towards the HN binding site. The increasing demand for the development of new drugs from sustainable sources demands the exploration of new sources as well as searching the existing sources for new compounds. Plants are definitely the first choice by chemists and pharmacists for this purpose due to their wide spectrum of pharmacological potential. The interest in Aegle marmelos has increased recently due to its claimed uses against COVID-19 [43-45]. The results indicate that in silico molecular docking is an efficient and rapid method of investigating molecular interaction and the mode of action of antiviral infection targeting bioactive compounds.

\section{Materials and Methods}

\subsection{Plant Material and Identification}

Leaves and ripened fruit of $A$. marmelos were collected from the local garden. In the field, plants were first identified by using standard keys and descriptions [46] and a voucher specimen GCU-151 was deposited in GCU-herbarium.

\subsection{Preparation of Plant Extract}

Powdered plant material ( $20 \mathrm{~g}$ ) was extracted using soxhlet apparatus at a temperature not reaching the boiling point of the solvent by using $200 \mathrm{~mL}$ of methanol $(99 \%)$ for 6 to $8 \mathrm{~h}$ and filtered. The filtrate was then concentrated in a rotary evaporator (Heidolph, 
model Laborata 4000 , Schwabach, Germany), at $40{ }^{\circ} \mathrm{C}$ to a thick gummy mass. The crude extract was lyophilized and preserved at $4{ }^{\circ} \mathrm{C}$ in airtight bags for future use. Stock solution $(1 \mathrm{mg} / \mathrm{mL})$ was prepared by dissolving the crude extracts in dimethyl sulphoxide (DMSO) solution.

\subsection{Phytochemical Contents}

\subsubsection{Total Phenolics Contents (TPC)}

The Folin-Ciocalteu colorimetric protocol of Singleton et al. [47] was used for estimation of TPC of extracts. Gallic acid solution was prepared by dissolving $10 \mathrm{mg}$ of it in $10 \mathrm{~mL}$ of methanol ( $1 \mathrm{mg} / \mathrm{mL})$. Various concentrations of the fruit and leaves extract $(25,50,75$, and $100 \mu \mathrm{g} / \mathrm{mL}$ ) and gallic acid were prepared separately. To each concentration, $5 \mathrm{~mL}$ of $10 \%$ Folin-Ciocalteu reagent and $4 \mathrm{~mL}$ of $7 \% \mathrm{Na}_{2} \mathrm{CO}_{3}$ were added, making a final volume of $10 \mathrm{~mL}$. The obtained blue colored mixture was shaken well and incubated for $30 \mathrm{~min}$ at $40{ }^{\circ} \mathrm{C}$ in a water bath. Then, the absorbance was measured at $760 \mathrm{~nm}$ against blank using a UV-visible spectrophotometer (Biotech Instruments, Winooski, VT, USA). The samples were prepared in triplicate for each analysis, and the average value of absorbance was used to plot the calibration curve to determine the level of phenolics in the extracts. Total phenolic contents of the extracts were calculated from the regression equation of calibration curve $\left(Y=0.0108 x ; R^{2}=0.993\right)$ and expressed as $\mathrm{mg}$ gallic acid equivalents per gram ( $\mathrm{mg}$ $\mathrm{GAE} / \mathrm{g}$ d.w) of sample in dry weight $(\mathrm{mg} / \mathrm{g})$.

\subsubsection{Total Flavonoids Contents (TFC)}

The Bao et al. [48] procedure with slight modifications was followed to calculate total flavonoid content (TFC) of fruit and leaves extracts of A. marmelos. Stock solutions of $4 \mathrm{mg} / \mathrm{mL}$ concentration the extracts were prepared and were diluted serially for different concentrations $(0.25,0.5,0.75$, and $1 \mathrm{mg} / \mathrm{mL})$ solutions. One $\mathrm{mL}$ of extract of each concentration was added to the test tube containing $4 \mathrm{~mL}$ of distilled water. At the same time, $0.3 \mathrm{~mL}$ of $5 \% \mathrm{NaNO}_{2}$ was added to the test tube and $0.3 \mathrm{~mL}$ of $10 \% \mathrm{AlCl}_{3}$ after $5 \mathrm{~min}$. Then, $2 \mathrm{~mL}$ of $1 \mathrm{M} \mathrm{NaOH}$ was added to the mixture after $6 \mathrm{~min}$. The volume of the mixture was increased to $10 \mathrm{~mL}$ by immediately adding $4.4 \mathrm{~mL}$ of distilled water. A procedure similar to that described was followed for the quercetin by dissolving $4 \mathrm{mg}$ of quercetin in $1 \mathrm{~mL}$ of methanol to make stock solution of $4 \mathrm{mg} / \mathrm{mL}$. Eventually, the absorbance of the mixtures was measured against reagent blank at $510 \mathrm{~nm}$ and TFC was noted of triplicate samples as mean \pm standard error. Total flavonoid contents (TFC) of the extracts were calculated from the regression equation of the calibration curve $\left(Y=0.0011 x ; R^{2}=0.992\right)$ and expressed as $\mathrm{mg}$ quercetin equivalents per gram $(\mathrm{mg} \mathrm{QE} / \mathrm{g})$ of sample in dry weight $(\mathrm{mg} / \mathrm{g})$.

\subsection{Antioxidant Analysis}

\subsubsection{DPPH Antioxidant Assay}

Protocol of Sylvie et al. [49] was followed to quantify the antioxidant potential of A. marmelos fruit and leaves using the DPPH assay. Various concentrations $(100-500 \mu \mathrm{g} / \mathrm{mL}$ d.w.) of $A$. marmelos fruit and leaves were mixed with methanolic solution of $1 \mathrm{~mL}$ and $0.4 \mathrm{mmol} / \mathrm{L}$ having DPPH radicals. After this, mixtures were placed in the black covered box for half an hour and, at the end, absorbance of each reaction mixture was noted at $520 \mathrm{~nm}$ via spectrophotometer (Biotech Instruments, Winooski, VT, USA). Inhibitory concentrations ( $\mathrm{IC}_{50}$ values) of the extracts were calculated from the graph as concentration versus percentage inhibition. Radical scavenging activity was expressed as percentage of inhibition. Measurements were taken in triplicate.

\subsubsection{FRAP Activity}

To check reducing power, both extracts were mixed (100-500 $\mu \mathrm{g} / \mathrm{mL}$ d.w) with a newly prepared phosphate buffer and 1\% Potassium ferricyante and heated for $20 \mathrm{~min}$ at $50{ }^{\circ} \mathrm{C}$. After $20 \mathrm{~min}$ of incubation, 10\% TCA was added and centrifuged for $10 \mathrm{~min}$ at 10,000 rpm. Then, the resulting supernatant was diluted with deionized water and 
(0.1 percent $w / v$ ) FeCl3 freshly prepared solution. The optical density of the mixture of reactions was observed at $700 \mathrm{~nm}$ [49]. All solutions were prepared freshly on the day of the experiment. Values were determined from a calibration curve obtained with Trolox solutions expressed as $\mu \mathrm{mol}$ trolox equivalent/g d.w at fixed concentrations, following the same procedure as for the extracted sample. Analyses were performed in triplicate on each extract.

\subsection{Biofilm Inhibition Assay}

Biofilm formation was performed using the procedure described earlier [50-63]. Tissue culture plates (96 wells) were filled with nutrient broth $(100 \mu \mathrm{L})$, bacterial suspension $(20 \mu \mathrm{L})$, and testing sample. Negative control well was filled with nutrient broth, $20 \mu \mathrm{L}$ bacterial, and $100 \mu \mathrm{L}$ of methanol solution. Then, all these plates were covered and incubated at $37^{\circ} \mathrm{C}$ for $24 \mathrm{~h}$. Each well was splashed with 3-time sterile phosphate buffer $(220 \mu \mathrm{L})$. Non-adherent bacteria were killed by gently shaking the wells. The residual was fixed with $220 \mu \mathrm{L}$ of methanol per well. After $15 \mathrm{~min}$, the plates were emptied and left to dry. The plates were stained with $220 \mathrm{~mL}$ of 50 percent crystal violet per well for $5 \mathrm{~min}$. The additional stain was rinsed off. After being air dried, the adherent cells were resolubilized with 33\% glacial acetic acid, $220 \mu \mathrm{L} /$ well. Using microplate reader (BioTek, Winooski, VT, USA), OD was calculated at $630 \mathrm{~nm}$. All the experiments against the E. coli bacterial strain were carried out three times and the consequences were averaged. The inhibition of bacterial growth (INH percent) was calculated using the following Equation (2):

$$
\text { inhibition } \%=\frac{100-(\text { OD630 sample } \times 100)}{\text { OD630 }}
$$

\subsection{In Ovo Antiviral Study}

NDV (Lasota) strain was bought from Poultry feed and vaccine store, Faisalabad, Pakistan. One-day-old layer eggs were incubated at $37^{\circ} \mathrm{C}$ for nine days. The virus $\operatorname{EID}_{50}$ was calculated as recorded by Young et al. [51].

\subsubsection{Egg Inoculation}

According to the procedure followed by Andleeb et al. [52], thirteen groups were formed $(n=5)$ and inoculated with different concentrations $(30,60,90,120 \mu \mathrm{g} / \mathrm{mL})$ of leaves and fruit extracts (Table 8). The eggs were then incubated at $37^{\circ} \mathrm{C}$ for $24 \mathrm{~h}$. The eggs were candled daily to check embryo efficiency. After 3 days, the eggs were cool. To detect $N D V$, allantoic fluid was collected from treated eggs to detect hemagglutination. The plant antiviral potential was based on embryos' survival rate.

Table 8. Grouping and treatment allocation for the in ovo assay.

\begin{tabular}{cc}
\hline Group $(\mathrm{G}) \boldsymbol{n = 5}$ & Treatment \\
\hline G1 & Untreated embryonated chicken egg (V-) \\
\hline G2 & NDV alone (V+) \\
\hline G3 & NDV + DMSO (VS+) \\
\hline G4\& G5 & Extract control (Fruit and Leaves) (E+) \\
\hline G6 to G9 & Methanolic fruit extract $(30,60,90,120 \mu \mathrm{g} / \mathrm{mL})+\mathrm{NDV}$ \\
\hline G10 to G13 & Methanolic leaf extract $(30,60,90,120 \mu \mathrm{g} / \mathrm{mL})+\mathrm{NDV}$ \\
\hline
\end{tabular}

\subsubsection{Hemagglutination Test}

The HA titer test was used following two-fold dilutions to measure the amount of the virus. The allantoic fluid was extracted from remaining embryonated eggs. In a 96-well, V-bottom-built microtiter tray, $50 \mu \mathrm{L}$ of normal saline was diluted serially from harvested allantoic fluid $(50 \mu \mathrm{L})$. Then, $50 \mu \mathrm{L}$ of 1 percent RBCs (freshly collected from chicken) was 
added to each well and gently mixed and allowed to settle at room temperature for $25 \mathrm{~min}$. Then, virus titer was noted as the highest dilution reciprocal that induced chicken RBC agglutination [53].

\subsection{In Silico Study}

\subsubsection{Swiss ADME Analysis}

A. marmelos contains phenols, alkaloids, flavonoids, couramins, carotenoids, tannins, and terpenoids. Twenty important bioactive compounds were selected due to their virtual bioactive properties towards antioxidant, antimicrobial, and antiviral efficacies [54-56]. The theoretical in silico study with ADME prediction of these compounds is enlisted in Table 3 using the online tool Swiss ADME (http:/ / www.sib.swiss, accessed on 15 July 2021). To predict appropriate properties, 2D structural models of compound were drawn to the SDF file and transmitted to SMILES (simplified molecular input line input system) presentation. Then, physiochemical properties such as molecular weight, number of hydrogen bond donors, number of hydrogen bond acceptors, molar refractivity, number of rotatable bonds, topological polar surface area (TPSA), and lipophilicity (ALogP) were examined. The drug-like efficacy of the selected compounds was tested for first round screening using Lipinski's rule of five based on the physiochemical properties $[28,57,58]$. Pharmacokinetics and medicinal properties were also examined.

\subsubsection{Molecular Docking Analysis}

The possible binding/interaction between proteins and ligands was explored using molecular docking studies. Three-dimensional structures of compounds were obtained from the protein data bank (PDB) database. Docking calculations have been performed using GOLD version 5.3.0 and BIOVIA discovery studio for modeling and visualizing (http://www.3dsbiovia.com, accessed on 15 July 2021) [59]. GOLD docking software version 5.3.0 was used for molecular docking studies and saved in PBD format. With the aid of GOLD, essential hydrogen atoms were added, affinity maps (grid) of $10 \AA$ and grid points with $0.75 \AA$ spacing were generated [60]. For energy minimization of ligands, chemdraw ultra 12.0 and chem $3 \mathrm{D}$ pro were used. The ligand atoms were supplemented with Gasteiger partial charges. Atoms of non-polar hydrogen were mixed, and rotatable bonds were identified. Then, ligands were downloaded from the PubChem software (https:/ / pubchem.ncbi.nlm.nih.gov, accessed on 15 July 2021) [61].

The molecular docking experiments were performed using molecular docking software parameters (https: / /www.ccdc.cam.ac.uk, accessed on 15 July 2021) [62]. The Lamarckian genetic algorithm (LGA) and the Solis and Wets local search method were used for docking simulations [63]. The initial position, orientation, and torsion of the molecules of the ligand were randomly set. Every docking experiment was extracted from 10 separate runs scheduled to end after a maximum of $1.5 \AA$ evaluations.

\subsubsection{Statistical Analysis}

The data were expressed as mean \pm S.E. One way analysis of variance (ANOVA) was conducted for statistical analysis of data, employing SPSS version 22.0. For statistical significance, $p<0.05$ was considered. Docking calculations were carried out by using GOLD version 5.3.0 and BIOVIA Discovery studio visualizer http:/ / www.3dsbiovia.com, accessed on 15 July 2021 [59].

\section{Conclusions}

It is clear from the above study that the methanolic extracts of $A$. marmelos leaves and fruit contain a variety of phytoconstituents that justify their applications for specific therapeutic impetus such as free radical scavenging, reducing power, antibiofilm potential, and antiviral efficacy against $N D V$. The extracts were safe antiviral agents at higher doses because of the declining and inhibiting proliferative response of $N D V$. The 20 compounds from A. marmelos are proven as potential drug molecules in terms of their pharmacokinetic 
and drug likeness. The molecular docking analysis suggested that marmenol, quercetin, catechin, marmelide, 6'7-epoxyauraptene, scopoletin, and scoparone inhibit the target protein $(\mathrm{HN})$ to bind with the host cell and work as potential ligands. Thus, this contemporary research can offer pharmacological evidence for the folkloric use of Aegle marmelos leaves and fruit, strongly revealing that the methanol extracts contain some active constituents that may be responsible for these activities. These preliminary findings provide systematic molecular and pharmacological knowledge, which may be an effective forum to promote the creation and design of new therapeutics.

Author Contributions: Conceptualization, A.A. and A.R.; Data Curation, N.Z. and M.U.I.; Validation, R.A. and F.T.; Formal analysis, R.A. and F.T.; Writing-Original Draft Preparation, H.T.A. and N.B.; Writing-Review \& Editing, R.A.M., M.U.I., H.T.A. and O.L.P. All authors have read and agreed to the published version of the manuscript.

Funding: This research was partially funded by UEFISCDI, grant number PN-III-P4-IDPCE-20202126 and FDI-0013.

Institutional Review Board Statement: Not applicable.

Informed Consent Statement: Not applicable.

Data Availability Statement: The data used to support the findings of this study are included in the article.

Acknowledgments: Not applicable.

Conflicts of Interest: The authors declare no conflict of interest.

\section{References}

1. Mayo, M.A. A Summary of Taxonomic Changes Recently Approved by ICTV. Arch. Virol. 2002, 147, 1655-1663. [CrossRef] [PubMed]

2. Lamb, R.A. Paramyxovirus Fusion a Hypothesis for Changes. Virology 1993, 197, 1-11. [CrossRef]

3. Ashraf, A.; Shah, M.S. Newcastle Disease: Present Status and Future Challenges for Developing Countries. Afr. Microbiol. Res. 2014, 8, 411-416. [CrossRef]

4. Xiao, S.; Paldurai, A.; Nayak, B.; Mirande, A.; Collins, P.L.; Samal, S.K. Complete Genome Sequence of a Highly Virulent Newcastle Disease Virus Currently Circulating in Mexico. Genome Announc. 2013, 1, 00177-12. [CrossRef]

5. Nogon, N.R.J.; Koanga, H.L.; Tchinda, T.A.; Magnifoeut, H.N.; Chieffo Motso, P.R.; MballaBounou, Z. Ethnobotanical Survey of Some Cameroonion Plants Used for the Treatment of Viral Disease. Afr. J. Plant. Sci. 2011, 5, 15-21.

6. Sajid, U.R.; Durrani, F.; Chand, N.; Khan, R.U.; Rehman, F. Comparative Efficacy of Different Schedules of Administration of Medicinal Plants Infusion on Hematology and Serum Biochemistry of Broiler Chicks. Res. Opin. Anim. Vet. Sci. 2011, 1, 8-14.

7. Sasidharan, S.; Chen, Y.; Saravanan, D.; Sundram, K.M.; Latha, L.Y. Extraction Isolation and Characterization of Bioactive Compounds from Plants Extract. Afr. J. Tradit. Complem. 2011, 8, 1-10. [CrossRef]

8. Oz, A.T.; Kafkas, E. Phytochemicals in Fruits and Vegetables. In Superfood and Functional Food; IntechOpen: London, UK, 2017; pp. 175-184.

9. Zia-Ul-Haq, M. Historical and Introductory Aspects of Carotenoids. In Carotenoids: Structure and Function in the Human Body; Zia-Ul-Haq, M., Dewanjee, S., Riaz, M., Eds.; Springer: Cham, Switzerland, 2021; pp. 1-42.

10. Li, G.; Gao, Q.; Yuan, S.; Wang, L.; Altmeyer, R.; Lan, K.; Yin, F.; Zou, G. Characterization of Three Small Molecule Inhibitors of Enterovirus 71 Identified from Screening of a Library of Natural Products. Antivir. Res. 2017, 143, 85-96. [CrossRef]

11. Yarmolinsky, L.; Zaccai, M.; Ben-Shabat, S.; Huleihel, M. AntiHerpetic Activity of Callissia Fragrans and Simmondsia Chinensis Leaf Extracts. Vitr. Open Virol. J. 2010, 4, 57-62. [CrossRef]

12. Zia-Ul-Haq, M. Past, Present and Future of Carotenoids Research. In Carotenoids: Structure and Function in the Human Body; Zia-Ul-Haq, M., Dewanjee, S., Riaz, M., Eds.; Springer: Cham, Switzerland, 2021; pp. 827-854.

13. Narayanaswamy, N.; Balakrishnan, K.P. Evaluation of Some Medicinal Plants for Their Antioxidant Properties. Int. J. Pharm. Tech. Res. 2011, 1, 381-385.

14. Aslam, M.S.; Ahmad, M.S. Worldwide Importance of Medicinal Plants Current and Historical Perspectives. Rec. Adv. Bio. Med. 2016, 2, 909. [CrossRef]

15. Kanwar, S.S.; Kapoor, R.; Sharma, B. Antiviral phytochemicals an overview. Biochem. Physiol. 2017, 6, 220.

16. Gohar, U.F.; Iqbal, I.; Shah, Z.; Mukhtar, H.; Zia-Ul-Haq, M. COVID-19: Recent Developments in Therapeutic Approaches. In Alternative Medicine Interventions for COVID-19; Zia-Ul-Haq, M., Bin-Jumah, M.N., Alothamn, S.I., Henidi, H.A., Eds.; Springer: Cham, Switzerland, 2021; pp. 249-274. 
17. Hay, M.; Thomas, D.W.; Craighead, J.L. Economides C and Rosenthal J Clinical Development Success Rates for Investigational Drugs. Nat. Biotechnol. 2014, 32, 40-51. [CrossRef] [PubMed]

18. Maity, P.; Hansda, D.; Bandyopadhyay, D.; Mishra, D.K. Biological Activities of Crude Extracts and Chemical Constituents of Bael Aegle marmelos (L). Corr. Indian J. Exp. Biol. 2009, 47, 849-861. [PubMed]

19. Asha, J.; Krishan, K. Tremendous Pharmacological Values of Aegle marmelos. Int. J. Pharma. Sci. Rev. Res. 2016, 36, 121-127.

20. Dutta, A.; Lal, N.; Naaz, M.; Ghosh, A.; Verma, R. Ethnological and Ethnomedicinal Importance of Aegle marmelos (L) Corr (Bael) among Indigenous People of India. Am. J. Ethnomed. 2014, 1, 290-312.

21. Jahan, I.; Tona, M.R.; Sharmin, S.; Sayeed, M.A.; Tania, F.Z.; Paul, A.; Chy, M.; Uddin, N.; Rakib, A.; Emran, T.B. GC-MS Phytochemical Profiling Pharmacological Properties and In Silico Studies of Chukrasia velutina Leaves a Novel Source for Bioactive Agents. Molecules 2020, 25, 3536. [CrossRef]

22. Rakib, A.; Paul, A.; Chy, M.; Uddin, N.; Sami, S.A.; Baral, S.K.; Majumder, M.; Tareq, A.M.; Amin, M.N.; Shahriar, A. Biochemical and Computational Approach of Selected Phytocompounds from Tinospora crispa in the Management of COVID-19. Molecules 2020, 25, 3936. [CrossRef] [PubMed]

23. Johari, M.A.; Khong, H.Y. Total Phenolic Content and Antioxidant and Antibacterial Activities of Pereskia bleo. Adv. Pharmacol. Sci. 2019, 2019. [CrossRef]

24. Khatun, A.; Rahman, M.; Rahman, M.M.; Hossain, H.; Jahan, I.A.; Nesa, M.L. Antioxidant, Antinociceptive and CNS Activities of Viscum orientale and High Sensitive Quantification of Bioactive Polyphenols by UPLC. Front. Pharm. 2016, 7, 176. [CrossRef]

25. Subhaswaraj, P.; Sowmya, M.; Jobina, R.; Sudharshan, S.J.; Dyavaiah, M.; Siddhardha, B. Determination of Antioxidant Potential of Acacia nilotica Leaf Extract in Oxidative Stress Response System of Saccharomyces cerevisiae. J. Sci. Food Agric. 2017, 97, 5247-5253. [CrossRef]

26. Kabesh, K.; Senthilkumar, P.; Ragunathan, R.; Kumar, R.R. Phytochemical Analysis of Catharanthus roseus Plant Extract and Its Antimicrobial Activity. Int. J. Pure App. Biosci. 2015, 3, 162-172.

27. Alswaidan, I.A.; Sooknah, K.; Rhyman, L.; Parlak, C.; Ndinteh, D.T.; Elzagheid, M.I.; Ramasami, P. 2,4-Ditellurouracil and its 5-Fluoro Derivative Theoretical Investigations of Structural Energetics and ADME Parameters. Comp. Bio. Chem. 2017, 68, 56-63. [CrossRef]

28. Testa, B.; Krämer, S.D. The Biochemistry of Drug Metabolism an Introduction Part 2 Redox Reactions and Their Enzymes. Chem. Biodivers. 2007, 4, 257-405. [CrossRef]

29. Meeran, S.; Baskar, V.; Tajudeen Syed, S.; Shabeer, T.K. Design ADME Profiling and Molecular Docking Simulation of New Isoniazid Schiff Base Analogs as MtKasB Inhibitors. Asian J. Res. Chem. Pharm. Sci. 2018, 6, $20-34$.

30. Lipinski, C.; Lombardo, A.; Dominy, F.; Feeney, P.J. Experimental and Computational Approaches to Estimate Solubility and Permeability in Drug Discovery and Development Settings. Adv. Drug Deliv. Rev. 2001, 46, 3. [CrossRef]

31. Baell, J.B.; Holloway, G.A. New Substructure Filters for Removal of Pan Assay Interference Compounds (PAINS) from Screening Libraries and for Their Exclusion in Bioassays. J. Med. Chem. 2010, 53, 2719-2740. [CrossRef]

32. Ritchie, T.J.; Ertl, P.; Lewis, R. The Graphical Representation of ADME-Related Molecule Properties for Medicinal Chemists. Drug Discov. Today 2011, 16, 65-72. [CrossRef]

33. Singh, S.; Singh, N. Phytochemical Analysis on Leaf Extract of Aegle marmelos. Int. J. Appl. Res. 2016, 2, 34-36.

34. Sahreen, S.; Khan, M.R.; Khan, R.A. Phenolic Compounds and Antioxidant Activities of Rumex hastatus D. Don. Leaves. J. Med. Plants Res. 2011, 5, 2755-2765.

35. Sánchez, E.; Rivas, M.C.; Castillo, S.; LeosRivas, C.; García, B.L.; Ortiz, D.M. Antibacterial and Antibiofilm Activity of Methanolic Plant Extracts against Nosocomial Microorganisms. Evid. Based Complement. Altern. Med. eCAM 2016, 8, 5-10. [CrossRef] [PubMed]

36. Eduardo, S.; Catalina, R.M.; Sandra, C.; Rivas, C.; Ledy, G.B.; David, M.M. Antibacterial and Antibiofillm Activity of Methanolic Plant Extracts Against Nosocomial Microorganisms. J. Evid. Based Complement. Altern. Med. 2016, 1, 1572697.

37. Sairengpuii, H.; Paramanantham, P.; Sampathkumar, R.; Dinakara, R.A.; Dhanasekhar, R.; Ranjith, N.K. Mosloflavone Attenuates the Quorum Sensing Controlled Virulence Phenotypes and Biofilm Formation in Pseudomonas aeruginosa PAO1: In vitro, In Vivo and In Silico Approach. Microb. Pathog. 2019, 31, 128-134.

38. Ashraf, A.; Ashraf, M.M.; Rafiqe, A.; Aslam, B.; Galani, S.; Zafar, S.; Asad, F.; Asghar, R.D.; Akram, S.; Ahmed, H.; et al. In vivo Antiviral Potential of Glycyrrhiza glabra Extract against Newcastle Disease Virus. Pak. J. Pharm. Sci. 2017, 30, 567-572.

39. Okoroafor, O.; Ezema, W.; Udegbunam, R.; Eze, J.; Eze, U.; Aronu, C.; Omornuwa, A.; Okosi, R.; Ngene, A. Immunologic and Haematologic Effects of Methanolic Stem Bark Extract of Azadihiracta indica on Chickens Experimentally Infected with Velogenic Newcastle Disease Virus (Kudu 113) Strain. Anim. Res. Int. 2015, 12, 2274.

40. Badam, L.; Bedekar, S.S.; Sonawane, K.B.; Joshi, S.P. In vitro Antiviral Activity of Bael (Aegle marmelos Corr) Upon Human Coxsackieviruses B1-B6. J. Comm. Dis. 2002, 34, 88-99.

41. Fromm, M.F. P-Glycoprotein a Defense Mechanism Limiting Oral Bioavailability and CNS Accumulation of Drugs. Int. J. Clin. Pharmacol. Ther. 2000, 38, 69-74. [CrossRef]

42. Szakacs, G.; Váradi, A.; Ozvegy Laczka, C.; Sarkadi, B. The Role of ABC Transporters in Drug Absorption Distribution Metabolism Excretion and Toxicity(ADME-Tox). Drug Discov. Today 2008, 13, 379-393. [CrossRef]

43. Zia-Ul-Haq, M.; Riaz, M.; Ahmedah, H.T. Carotenoids and Periodontal Diseases. In Carotenoids: Structure and Function in the Human Body; Zia-Ul-Haq, M., Dewanjee, S., Riaz, M., Eds.; Springer: Cham, Switzerland, 2021; pp. 715-720. 
44. Zia-Ul-Haq, M.; Riaz, M.; Modhi, A.O. Carotenoids and Bone Health. In Carotenoids: Structure and Function in the Human Body; Zia-Ul-Haq, M., Dewanjee, S., Riaz, M., Eds.; Springer: Cham, Switzerland, 2021; pp. 697-713.

45. Yadav, V.K.; Singh, G.; Jha, R.K.; Kaushik, P. Visiting Bael (Aegle marmelos) as a Protective Agent against COVID-19: A Review. Indian J. Trad. Know. 2020, 19, 153-157.

46. Dalziel, J.M. The Useful Plants of West Tropical Africa Crown Agents for Oversea Governments and Administration; Crown Agents for the Colonies: London, UK, 1955; p. 147.

47. Singleton, V.L.; Orthofer, R.; Lamuela-Raventos, R.M. Analysis of Total Phenols and Other Oxidation Substrates and Antioxidants by Means of Folin-Ciocalteu Reagent. Method. Enzym. 1999, 299, 152-178.

48. Bao, J.; Cai, Y.; Sun, M.; Wang, G.; Corke, H. Anthocyanins, Flavonols, and Free Radical Scavenging Activity of Chinese Bayberry (Myrica rubra) Extracts and Their Color Properties and Stability. J. Agri. Food Chem. 2005, 53, 2327-2332. [CrossRef]

49. Sylvie, D.D.; Anatole, P.C.; Cabral, B.P. Veronique Comparison of In Vitro Antioxidant Properties of Extracts from Three Plants Used for Medical Purpose in Cameroon Acalypha racemosa, Garcinia lucida and Hymenocardia lyrata. Asian Pac. J. Trop. Biomed. 2014, 4, S625-S632. [CrossRef]

50. Shabbir, H.; Ali, S.; Shahzadi, S.; Rizzoli, C.; Shahid, M. Diorganotin (IV) Complexes with Monohydrate Disodium Salt of Iminodiacetic Acid Synthesis Characterization Crystal Structure and Biological Activities. J. Chin. Chem. 2015, 62, 793-802.

51. Young, M.B.; Alders, R.; Grimes, S.; Spradbrow, P.B.; Dias, P.; Silva, A.D.; Lobo, Q. Controlling Newcastle Disease in Village Chickens: A Laboratory Manual, 2nd ed.; ACIARMonographs No. 87; Australian Centre for International Agricultural Research: Canberra, Australia, 2002.

52. Andleeb, R.; Ashraf, A.; Muzammil, S.; Naz, S.; Asad, F.; Ali, T.; Rafi, R.; Al-Ghanim, K.A.; Al-Misned, F.; Ahmed, Z.; et al. Analysis of Bioactive Composites and Antiviral Activity of Iresine herbstii Extracts against Newcastle Disease Virus in Ovo. Saudi J. Biol. Sci. 2020, 27, 335-340. [CrossRef] [PubMed]

53. Andleeb, R.; Ashraf, A.; Asad, F.; Ijaz, M.U. In Vitro Antioxidant, Hemolytic, Thrombolytic Potencies of Centratherum anthelminticum Seed Extracts and It's in Ovo Antiviral Efficacy. Pak. J. Agri. Sci. 2020, 57, 1261-1269.

54. Murthy, H.N.; Bhat, M.A.; Dalawai, D. Bioactive Compounds of Bael (Aegle marmelos (L.) Correa). In Bioactive Compounds in Underutilized Fruits and Nuts; Springer: Berlin/Heidelberg, Germany, 2020; pp. 459-486.

55. Venthodika, A.; Chhikara, N.; Mann, S.; Garg, M.K.; Sofi, S.A.; Panghal, A. Bioactive Review. Phytother. Res. 2021, 35, 1887-1907. [CrossRef]

56. Rahman, S.; Parvin, R. Therapeutic Potential of Aegle marmelos (L) An Overview. Asian Pac. J. Trop. Dis. 2014, 4, 71-77. [CrossRef]

57. Veber, D.F.; Johnson, S.R.; Cheng, H.Y.; Smith, B.R.; Ward, K.W.; Kopple, K.D. Molecular Properties That Influence the Oral Bioavailability of Drug Candidates. J. Med. Chem. 2002, 45, 2615-2623. [CrossRef]

58. Ghose, A.K.; Viswanadhan, V.N.; Wendoloski, J.J. A Knowledge-Based Approach in Designing Combinatorial or Medicinal Chemistry Libraries for Drug Discovery 1 a Qualitative and Quantitative Characterization of Known Drug Databases. J. Combin. Chem. 1999, 1, 55-68. [CrossRef]

59. Available online: http:/ / www.3dsbiovia.com (accessed on 15 July 2021).

60. Kumar, P.; Khanna, M.; Srivastava, V.; Tyagi, Y.K.; Raj, H.G.; Ravi, K. Effect of Quercetin Supplementation on Lung Antioxidants after Experimental Influenza Virus Infection. Exp. Lung Res. 2005, 31, 449-459. [CrossRef]

61. Available online: https:/ / pubchem.ncbi.nlm.nih.gov (accessed on 15 July 2021).

62. Available online: https://www.ccdc.cam.ac.uk (accessed on 15 July 2021).

63. Solis, F.J. Wets Minimization by Random Search Techniques. Math. Oper. Res. 1981, 6, 19-30. [CrossRef] 